\title{
The International Politics of IFRS Harmonization
}

\section{Citation}

Ramanna, Karthik. "The International Politics of IFRS Harmonization." Accounting, Economics and Law 3, no. 2 (April 2013): 1-46.

\section{Published Version}

http://www.degruyter.com/dg/viewarticle.fullcontentlink:pdfeventlink/\$002fj

$\$ 002$ fael.2013.3.issue-2\$002fael-2013-0004\$002fael-2013-0004.pdf?format=INT\&t:ac=j

$\$ 002 f a e l .2013 .3$.issue-2\$002fael-2013-0004\$002fael-2013-0004.xml

\section{Permanent link}

http://nrs.harvard.edu/urn-3:HUL.InstRepos:11320610

\section{Terms of Use}

This article was downloaded from Harvard University's DASH repository, and is made available under the terms and conditions applicable to Open Access Policy Articles, as set forth at http:// nrs.harvard.edu/urn-3:HUL.InstRepos:dash.current.terms-of-use\#OAP

\section{Share Your Story}

The Harvard community has made this article openly available.

Please share how this access benefits you. Submit a story.

\section{Accessibility}


H A R VAR D

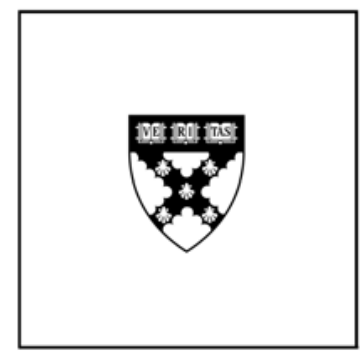

\title{
The international politics of IFRS harmonization
}

\author{
Karthik Ramanna
}

\section{Working Paper}

\section{$11-132$}

August 27, 2012 


\title{
The international politics of IFRS harmonization"
}

\author{
Karthik Ramanna \\ Harvard Business School
}

First draft: June 28, 2011

This draft: August 27, 2012

\begin{abstract}
The globalization of accounting standards as seen through the proliferation of IFRS worldwide is one of the most important developments in corporate governance over the last decade. I offer an analysis of some international political dynamics of countries' IFRS harmonization decisions. The analysis is based on field studies in three jurisdictions: Canada, China, and India. Across these jurisdictions, I first describe unique elements of domestic political economies that are shaping IFRS policies. Then, I inductively isolate two principal dimensions that can be used to characterize the jurisdictions' IFRS responses: proximity to existing political powers at the IASB; and own potential political power at the IASB. Based on how countries are classified along these dimensions, I offer predictions, ceteris paribus, on countries' IFRS harmonization strategies. The analysis and framework in this paper can help broaden the understanding of accounting's globalization.
\end{abstract}

Keywords: accounting standards, globalization, IASB, IFRS, politics

JEL Classification Codes: D72, F53, G15, K33, M16, M41

\footnotetext{
${ }^{*}$ Special thanks to my research associates on the various HBS case studies that serve as primary data for the analysis in this paper: Daniela Beyersdorfer, Beiting Cheng, Nancy Dai, G.A. Donovan, Karol Misztal, and Rachna Tahilyani. I also appreciate helpful comments from Yuri Biondi, David Hawkins, Paul Healy, Bob Kaplan, Richard Macve, Anette Mikes, Krishna Palepu, Bob Simons, Ross Watts, Steve Zeff, the anonymous reviewers, and workshop participants at HBS and Chinese University of Hong Kong; excellent research assistance from Scott Renner; and financial support from HBS. I alone am responsible for any errors.
} 
TABLE OF CONTENTS

1. INTRODUCTION

2. BACKGROUND

2.1. RELATED THEORY

2.2. INSTITUTIONAL BACKGROUND: BRITISH AND EU CENTRALITY TO THE IASB

3. JUNIOR ALLIES: THE CASE OF CANADA

3.1. THE ECONOMIC RATIONALE FOR GLOBALIZING CANADIAN ACCOUNTING STANDARDS

3.2. CULTURAL EXPLANATIONS FOR CANADA's IFRS ADOPTION

4. TOWARDS A MULTIPOLAR IASB: THE CASE OF CHINA

4.1. CHINA'S UNIQUE ECONOMIC MOTIVES FOR IFRS ADOPTION

4.2. THE INTERNATIONAL POLITICAL ECONOMY OF CHINA AND THE IASB

5. BIGGER FISH FROM SMALLER PONDS: THE CASE OF TATA STEEL IN INDIA

5.1. ACCOUNTING AND GLOBALIZATION AT TATA STEEL

5.2. THE CALCULUS OF IFRS IN INDIA

6. THE INTERNATIONAL POLITICS OF IFRS HARMONIZATION

6.1. AN INDUCTIVE FRAMEWORK

6.2. THE SPECIAL CASE OF THE UNITED STATES

7. DISCUSSION

7.1. IMPLICATIONS FOR IFRS-RELATED ISSUES IN PRACTICE

7.2. RESEARCH IMPLICATIONS

8. CONCLUSION 


\section{Introduction}

The globalization of accounting standards through the development and growth, since 2001, of International Financial Reporting Standards (IFRS) is one of the most important phenomena in corporate governance today. In an ironic twist to its staid perception in popular culture, accounting has been at the forefront of globalization: ahead in its efforts to converge standards internationally when compared to other related areas such as product quality standards, occupational safety standards, environmental standards, securities law, immigration reform, etc. Since the early 2000 s, several countries, particularly member-states of the European Union (EU), have embarked on a project to unite globally divergent accounting standards into one common set of accounting principles, IFRS. As of 2010, about 100 countries, including all of the world's major economies, either have adopted IFRS, or have initiated an IFRS harmonization program, or have in place some national strategy to respond to IFRS.

Over the 2001-2010 period, countries have varied in the degree and timing of their commitment to IFRS. There are a number of plausible hypotheses for this variation, including cultural differences, differences in corporate governance environments, technological differences, and differences in countries' natural resources. ${ }^{1}$ In this paper, I investigate how some of these fundamental jurisdictional differences manifest into international political dynamics that can contribute to countries' responses to IFRS. Through in-depth field studies across three jurisdictions - Canada, China, and India - I develop a framework that can help characterize the international political dynamics of the globalization of accounting standards. The framework is represented by a two-dimensional matrix, where: one dimension represents a jurisdiction's proximity to existing political powers at the IFRS' rule-making body, the International Accounting Standards Board (IASB); and the other dimension represents a jurisdiction's own potential political power at the IASB. The framework can help explain and predict countries' decisions on IFRS harmonization and can yield insights into the nature of IFRS itself and its potential structure in the future.

I begin my analysis by first briefly providing (in Section 2, "Background") some theoretical basis for my study of "international politics" and "power." To do this, I connect the study to the related literatures on the political process in accounting, on political economy, and on international relations. Across these literatures, the terms "politics" and "power" have many interpretations (based on the underlying branch of social science-economics, political science, or sociology); I am agnostic on these definitions because they do not detract from

\footnotetext{
${ }^{1}$ On the complementarities of accounting standards with local institutions, see, for example, Ball, Kothari, and Robin (2000), Ball (2006), and Leuz (2010). Ramanna and Sletten (2009) discuss hypotheses on the degree and timing of countries' IFRS harmonization.
} 
the study's conclusions. But for clarity, "politics" can be understood as the deliberative (i.e., non-price-based) allocation of scare resources (in this case, IFRS standard setting) across entities with heterogeneous preferences. The politics here is "international" because the "entities" are countries. ${ }^{2}$ One interpretation of political "power" is the ability of an entity to further its preferences in a deliberative allocation through sanctions (or threats thereof) on another (e.g., Bowles and Gintis, 1993).

In addition to theoretical background, Section 2 provides a background to the development of IFRS over its first decade, particularly examining the role of Britain and the EU in the establishment and subsequent direction of the IASB. This description is important to my study because it helps establish the existing political power base at the IASB, against which other jurisdictions' IFRS harmonization responses can be evaluated. I survey the historical evidence on the IASB's first decade and conclude that the IASB has been, since its inception, legitimized by the EU embrace of IFRS and defined by, in particular, British interests. For example, Britain had a formative role in the predecessor institutions to the IASB (Camfferman and Zeff, 2007), and there is anecdotal evidence from modifications to IFRS at the behest of certain large EU member states during the 2008-09 financial crisis suggesting that preserving the EU's reliance on IFRS is an important source of legitimacy for the IASB. (There are, of course, differences within the EU on the direction and desirability of IFRS, which I discuss in the paper; but, for the most part, these differences are subsumed in my treatment of the EU as a single entity. The advantage of this treatment is that it allows for a richer exploration of the international political dynamics of non-EU countries' approaches to IFRS - the politics of the EU being well studied. ${ }^{3}$ I elaborate on this point in Section 2.)

In the context of the IASB's British origins and EU mandate, Canada's decision to adopt IFRS provides important insights. In 2005, faced with increasingly globalized product and capital markets, and with the growing popularity of IFRS across the globe, Canadian capital market regulators considered abandoning their domestic accounting standards for IFRS (Canada had been involved in efforts to develop international accounting standards since the 1970s). A significant fraction of Canadian industry (especially oil and gas companies), however, opposed this idea, arguing instead that Canada adopt U.S. Generally Accepted Accounting Principles (GAAP). With over 80\% of its exports being U.S. bound, and over $60 \%$ of its foreign equity portfolio investment from the United States, the position that Canada adopt U.S. GAAP had strong merits.

\footnotetext{
${ }^{2}$ In using countries as the unit of analysis, I subsume the domestic political economies that generate country-level responses into intra-national forces. See Section 2.

${ }^{3}$ See for example, Leuz, Pfaff, and Hopwood (2005), Benston, Bromwich, Litan, and Wagenhofer (2006), and Botzem (2012).
} 
Nevertheless, Canadian regulators decided to embrace IFRS. The Canadian decision is interesting in that it bucked economic arguments for U.S. GAAP adoption and put Canadian capital markets at the discretion of rules set by the London-based IASB. ${ }^{4}$ Section 3, "Junior allies: the case of Canada," explores this counter-intuitive decision. Ultimately, I identify two non-market forces as likely contributing to the decision: (1) Canadian comfort with the IASB's Anglocentrism, particularly when viewed in the context of longstanding cultural ties with Britain; and (2) Canada's resonant desire to distinguish itself from the United States, despite its strong cultural ties to that country (in light of what the Canadian media has described as an "inferiority complex" vis-à-vis America).

Contrasting Canada's near complete commitment to IFRS, China's IFRS approach highlights the result of political compromises in the IFRS harmonization process. (Unlike Canadian "adoption" of IFRS, since 2006, China has issued IFRS "converged" domestic accounting standards. ${ }^{5}$ ) This issue is discussed in Section 4, "Towards a multipolar IASB: the case of China." Citing China's "unique circumstances," the Ministry of Finance (MOF) in Beijing has been careful to customize IFRS to its needs where expedient. For instance, given state ownership of a substantial proportion of Chinese companies, the MOF noted that many state entities were likely to be subject to extensive related-party disclosure requirements under a strict interpretation of IFRS. Arguing against the onerous nature of such compliance, the MOF was able to successfully lobby the IASB to modify IFRS so that its state-owned enterprises were not subject to the same level of related-party disclosures as most other companies across the world. The substantive element of this victory is significant because the disclosure of relatedparty transactions is central to maintaining the integrity of the "entity concept," the fundamental idea in accounting that an enterprise's financials are its own. On a procedural level, the victory can be indicative of the MOF's growing power at the IASB and its ability to shape IFRS in the future.

While the Chinese government has been successful in making its voice heard at the IASB, the ability of other emerging markets to do so is less clear. This issue is the focus of Section 5, "Bigger fish from smaller ponds: the case of Tata Steel in India." Tata Steel is a large Indian multinational with extensive European operations funded by euro denominated debt. This natural hedge notwithstanding, Tata Steel is required under IFRS rules to translate the debt into its home currency, Indian rupees, for consolidated reporting purposes. Given the

\footnotetext{
${ }^{4}$ Technically, an IFRS standard must be included in the Canadian Institute of Chartered Accountants' Handbook in order to be considered Canadian GAAP. Thus, Canada has an "opt-in" rather than an "opt-out" mechanism to IFRS harmonization, which could make it easier for Canada to reject an IFRS standard in the future should the need arise.

${ }^{5}$ The distinction between "adoption" and "convergence" colors the IFRS response strategies of several other countries, e.g., Japan. See Section 7.
} 
rupee's volatility, the IFRS translation requirement exposes Tata Steel's financial statements to substantial mechanical swings (about 64\% of net income in 2009), affecting its financial covenants and its ability to raise further capital. I discuss the challenges faced by Tata Steel in organizing a response to the problem above. I conclude that concerns such as those faced by Tata Steel can help explain India's decision to defer its IFRS convergence project twice in the past two years. The Tata case study has implications for the IFRS response strategies of other countries with similar or less international power than India.

The country analyses outlined above can be used to induce a framework to analyze how international politics can shape countries' strategies on IFRS harmonization (Figure 3, Section 6). The framework is characterized by a twodimensional matrix where: (i) one axis represents a country's proximity to the existing political powers at the IASB; and (ii) the other axis a country's potential political power, i.e., its ability to shape decisions at the IASB. In (i), "proximity" is essentially a measure of cultural distance, where "culture" is defined as a set of shared beliefs and preferences across entities (e.g., Fernández, 2008). For example, Canada, with its British roots, scores high on the proximity dimension. China, for reasons briefly illustrated above, scores high on the second dimension, potential political power. In Section 6, "The international politics of IFRS harmonization," I discuss how a classification of countries along the two dimensions can be used to help explain and predict their IFRS response strategies on the basis of international political dynamics. Specifically, ceteris paribus, I expect: (1) countries scoring high on the first dimension but low on the second (i.e., countries with high proximity to the existing IASB political powers, but low potential political power, e.g., New Zealand) are likely to embrace IFRS (as Canada has); (2) countries scoring low on the first dimension but high on the second (e.g., Japan) are likely to develop expedient exceptions as part of their IFRS response strategy (as China has); and (3) countries scoring low on both dimensions are likely to either slow IFRS harmonization (as India has) or work in regional coalitions to gain a stronger voice in IASB decision making (as Singapore has). In this section, I also briefly discuss the special case of the United States on IFRS harmonization. The United States is at once one of the IASB's most powerful constituents and most reluctant endorsers, a contradiction that reflects its unique role in IFRS international politics.

There are both practical and academic implications of the framework described above that I briefly address in Section 7, "Discussion." On practical implications, I discuss how the paper's framework can relate to the IASB's strategy to encourage "full adoption" over "convergence" among potential harmonizing jurisdictions and to the IASB's own organizational reforms to increase the board's geographical diversity. I expect both the "full adoption" strategy and the organizational reforms to increase the role of power politics in 
IFRS standard setting. On academic implications, I connect the paper's framework to what, I argue, is likely to be the central question in IFRS standardsetting research going forward-'Is the political process underlying IFRS facilitating the production of economically efficient standards?'

A brief note on the paper's research methodology is in order. The paper has three objectives: (1) to describe salient elements influencing the IFRS harmonization process in three field sites - Canada, China, and India; (2) to isolate from these descriptions dimensions of international politics in the countries' harmonization decisions; and (3) to offer predictions and explanations for other countries' decisions on IFRS harmonization. In this sense, the paper focuses on "moving from bottom to top" in "three steps-observation, categorization and association," and thus can be said to follow an "inductive theory building process" (Carlile and Christensen, 2004, p. 4, emphasis in original). The inductive approach is "positive" because it presupposes an epistemology that empirical reality "can be studied through objective categories" (Ahrens and Chapman, 2006, p. 822) ${ }^{6}$ but it is distinct from much of the other positive IFRS-related literature that is most commonly large-sample statistical (i.e., "top to bottom" deductive research).

I conclude with a caveat: While the dimensions of international political dynamics outlined in this paper can have explanatory power in understanding countries' IFRS harmonization decisions, they are not intended to be exhaustive. Big 4 audit firms, large global financial firms, and multinational industrial companies may impact international political dynamics independent of the country-level forces highlighted herein. ${ }^{7}$ Moreover, "international politics" is not the only element in understanding the proliferation of IFRS. Thus, the framework presented here is at best a "partial equilibrium" analysis.

\section{Background}

\subsection{Related theory}

There is a robust literature on the political process in accounting, in the historical (e.g., Zeff, 1972), the economic (e.g., Watts and Zimmerman, 1978), and the sociological traditions (e.g., Power, 1992). The 'qualitative' literature has

\footnotetext{
${ }^{6}$ Thus, although the paper's "domain" is the field, it is distinct from "qualitative" field research, which presupposes "emergent, subjective, and constructed properties" in the data (Ahrens and Chapman).

${ }^{7}$ There is an evolving literature on the role of private actors, such as the Big 4 auditors, in IFRS harmonization that is complementary to the analysis herein: See, for example, Botzem and Quack (2009) and references therein, particularly, Perry and Nölke (2005); also, Perry and Nölke (2006).
} 
approached the political process as 'emergent,' arguing that a standard-setting institution both responds to and "contributes to changes in [its] environment" (e.g., Young, 1994, p. 84). By contrast, the 'positive' literature has attempted to find deterministic relations in standard setting, mostly through a focus on firms and auditors as the unit of analysis (e.g., Watts and Zimmerman, 1982; Puro, 1984), although there are also studies that investigate the effects of other standard-setting constituencies such as politicians (e.g., Ramanna, 2008) and the standard setters themselves (e.g., Allen and Ramanna, 2012). A key objective of the literature is to describe and understand the determination of national accounting standards, a process that is "political" (rather than "economic") because it involves allocating scarce resources (by establishing rules) across entities with heterogeneous preferences through a deliberative (i.e., non-market) process. Outcomes of the deliberative resource-allocation process are affected by the entities' differing (political) power, where such "power" can be understood as "the ability of furthering one's interests by imposing (or credibly threatening to impose) sanctions on another [entity] when the converse is not also true" (Bowles and Gintis, 1993, p. 88). ${ }^{8}$ In a utilitarian sense, insights into the political process of accounting are informative because they shed light on whether accounting is likely to facilitate allocative efficiency in a capitalist economy.

In this tradition of political studies in accounting, I offer an analysis of international politics in IFRS harmonization. There are two important distinctions between this analysis and much of the political literature in accounting. First, the analysis is "international." This means that the "political process" is not contained within relatively well-defined government institutions such as legislative or legal authority, which can afford a procedural "legitimacy." International politics, as the literature in international relations has observed (e.g., Büthe and Mattli, 2011), often occurs outside the rules or norms established by governments and their laws. This lack of procedural legitimacy makes it difficult to evaluate the allocative efficiency of outcomes from an international political process.

Second, the analysis is at the level of "countries." While this is common in the literatures on international relations and international corporate governance (e.g., La Porta, Lopez-de-Silanes, and Shleifer, 2008), it is by no means necessary to a study of international politics, as seen in the some of IFRS literature (e.g., Perry and Nölke, 2005; Büthe and Mattli, 2011; Botzem, 2012) and in the broader

\footnotetext{
${ }^{8}$ The Bowles and Gintis definition of "power" uses the vocabulary of neoclassical economics. A broader, sociological definition of power is provided by Weber (1947): "the probability that one actor within a social relationship would be in a position to carry out his own will despite resistance." Also see Hope and Gray (1982) for an examination of political "power" in accounting standard-setting.

${ }^{9}$ Hurrell (2005, p. 16) defines "legitimacy" as resulting in rule following that is "distinguishable from purely self-interested or instrumental behavior on the one hand, and from straightforward imposed or coercive rule on the other."
} 
literature on the politics of multinational corporations. ${ }^{10}$ Moreover, most of the accounting literature on IFRS is at the firm level. But countries as a unit of analysis are useful to studying accounting globalization because eventually decisions about requiring, permitting, or eschewing IFRS for companies are made at the country level (usually by a public authority or a public-mandate agency). Of course, country-level decisions reflect domestic political economies, which are driven in part by the relative preferences and power of local firms, politicians, and standard setters, as the following sections on Canada, China, and India illustrate. Further, the existence and nature of local procedural institutions such public hearings or industry clubs can also affect country-level outcomes. ${ }^{11}$ In using countries as the unit of analysis, I subsume the domestic political economies that generate country-level responses into intra-national forces. Thus, I argue, I can isolate dimensions of "international politics" for use in cross-country comparative studies.

\subsection{Institutional background: British and EU centrality to the IASB}

This subsection briefly surveys the evidence on EU and, in particular, British centrality to the IASB's origins and development. The objective is to establish the IASB's core political identity, which is useful in the comparative analysis that follows.

The development of national accounting "standards" is itself a relatively recent phenomenon (e.g., Baxter, 1981), dating only to the post-World War II era, so the internationalization of accounting standards is still more recent. ${ }^{12}$ An early systematic attempt at harmonizing standards across borders was the Accountants International Study Group (AISG), established in 1967. Three countries, Canada, the UK, and the United States, were part of this effort, which involved comparing the jurisdictions' accounting and auditing practices with a view towards reducing differences (Camfferman and Zeff, 2007, p. 30).

Paralleling the development of the AISG, were efforts within the European Economic Community (of which the UK was not as yet a member) at accounting standards harmonization. These efforts had made significant progress by 1973 when the UK joined the EEC. In part to ensure its voice in European accounting harmonization in light of already established Continental momentum

\footnotetext{
${ }^{10}$ On the politics of multinational corporations, Nye (1974) is an early study. More recently in accounting, Humphrey, Loft, and Woods (2009) study the interplay of large audit firms and the "international financial architecture" during the 2008-09 financial crisis.

${ }^{11}$ On the role of procedural institutions, see, for example, Richardson's (2009) network-centric study of the Canadian accounting establishment.

12 Baxter makes the distinction between pre-War U.S. GAAP that generally reflected the codification of widely accepted accounting practices, and post-War U.S. accounting "standards" that were motivated from conceptual ideas and thus did not always reflect existing practice.
} 
in this regard, the UK led in the establishment of a new group, the International Accounting Standards Committee (IASC), the same year (Benston et al., 2006, p. 229). ${ }^{13}$

The IASC marked a major development in the globalization of accounting standards. The London-based IASC was an association of the professional accountancy bodies from Australia, Canada, France, Germany, Japan, Mexico, the Netherlands, the UK and Ireland, and the United States. The IASC was explicitly concerned with narrowing differences in accounting practices across its member states, a task it saw as important in light of increasing international trade (e.g., Camfferman and Zeff, 2007). The IASC had no specific intergovernmental mandate and no statutory enforcement authority. Perhaps in light of these limitations, the IASC focused on developing broad accounting principles with an eye on influencing jurisdiction-based accounting regulations, rather than on creating international accounting standards per se (e.g., Donnelly, 2010, p. 229).

By the 1990s, there was growing consensus that the IASC's indirect approach to globalizing accounting standards was insufficient (Camfferman and Zeff, 2007, p. 447). The idea of a professionally organized, technocratic standardsetting institution, with a direct objective to produce common worldwide accounting rules, came to take root. Early in the new millennium, the IASB was born.

The London-based IASB had from the beginning the EU's backing. The European Commission (EC), which was already pushing for a single set of accounting standards across its "common market," wanted to play a more important role in the worldwide harmonization of financial reporting and thus avoid U.S. dominance of this process (Camfferman and Zeff, 2007, p. 17). In 2000 , the EC designated the as-yet-unborn IASB its de facto standard setter, and in 2002, the European Parliament required all EU-listed companies to report under IFRS from 2005 (European Parliament, 2002). ${ }^{14}$ The first IASB chairman was Britain's then chief accounting standard setter, David Tweedie.

Just as EU and, in particular, British interests were central to the IASB's foundation, these interests continued to shape the IASB's development through its first decade. A palpable example of the EU's centrality to the IASB came during the 2008-09 financial crisis. The issue at hand was IAS 39 and IFRS 7, the extant international standards on measurement, recognition, and disclosure of financial

\footnotetext{
${ }^{13}$ Camfferman and Zeff (Ch. 3) discuss other motives behind the formation of the IASC. Their discussion highlights the UK's central role, particularly through the activities of Lord Benson, president of the Institute of Chartered Accountants in England and Wales, whom they describe as (p. 44) "the guiding spirit behind the founding of the IASC."

${ }_{14}$ Technically, the EU maintains an independent process to evaluate each IFRS. Due to modifications that can emerge in this process, the EU-version of IFRS is not identical to that issued by the IASB.
} 
instruments. The standards did not provide companies the flexibility to reclassify financial instruments hitherto accounted for using fair values to a historical cost basis. This situation considerably inconvenienced several major European banks at the height of the financial crisis when the fair values of many asset classes were depressed. The banks argued that certain assets (including mortgage-based assets) were expected to be held for very long periods, so transitory depressions in their fair values should not affect bank balance sheets. They sought a reclassification of these assets to a cost basis. ${ }^{15}$

Buttressing the banks' claim was a similar reclassification provision in U.S. GAAP (e.g., Christoffersen, 2008). Arguing for a "level playing field" with the Americans, the EC's Economic and Financial Affairs Council, under pressure from major players in the European banking industry, called on the IASB on October 7, 2008 to address the issue (EC, 2008). On October 8, the EC president threatened legislation to create a European carve-out from IFRS on reclassification, a move that could have subverted the IASB's legitimacy in the midst of the financial crisis. On October 13, the IASB rushed through amendments that gave the banks the ability to reclassify previously fair-valued assets to a cost basis, a decision backdated to July $1 .{ }^{16}$ The decision likely compromised the IASB's emerging reputation for due process in decision making (e.g., Leone, 2008). While the EC's influence over the IASB in this matter was not unequivocal, it is pertinent to note that the IASB - at some damage to itselfhurriedly caved to the EC's threat of subverting IFRS on the subject.

Evidence on the EU's centrality to the IASB can also be seen in more formal empirical tests. For example, Ramanna and Sletten (2011) conduct a study to test for the presence of network effects in the decisions of over 90 non-EU countries to adopt IFRS. They find robust evidence consistent with network effects. Interestingly, they find that (p. 27) "network benefits expected to accrue from economic relations with the EU" are a "dominant" source of the network effects. This latter conclusion is especially true for larger countries. The authors cite the anecdotal evidence from Skinner's (2008) work on Japan as consistent with this conclusion. Skinner (p. 220) notes that IFRS harmonization attempts in Japan arose from pressure to "convince" the EU "that Japanese GAAP was 'equivalent' to IFRS," since "Japanese companies rely heavily on European capital markets for external debt financing."

The historical, political, and empirical evidence briefly discussed above are consistent with the EU and, in particular, Britain being central to the origin and development of the IASB. This conclusion is not particularly controversial, but establishing it is important to the following analysis. The IASB's European

\footnotetext{
${ }^{15}$ See, for example, Norris (2010) and the discussion and citations in Laux and Leuz (2009).

${ }^{16}$ Reclassifying entities were required to disclose in footnotes results absent reclassification.
} 
identity institutes a baseline against which other jurisdictions' IFRS harmonization responses can be evaluated.

There are, of course, limitations to treating Britain and the EU as a common unit; particularly given that EC decisions are often not unanimous and that Continental European accounting traditions are sometimes at odds with those in Britain. In fact, on some dimensions, British accounting traditions-e.g., in their relation to the Common Law - are closer to U.S. GAAP than European accounting practices. However, at least since 2005, IFRS has been applied universally through the EU (including Britain), so it is reasonable to treat the region as a common accounting jurisdiction. Similarly, on the issue of discord within the EU on the direction of IFRS, this is certainly an active area for study; but viewed at a global level from an extro-Europe perspective, particularly over the IASB's first decade, the EU remains a useful jurisdictional unit for an international comparative study. (I return to the issue of intra-EU discords on IFRS in Section 7) In other words, acknowledging that the EU is not a monolith and that differences within the EU warrant much attention, I argue that EU's collective embrace of IFRS, together with the evidence on the EU's role in the origins and development of the IASB merit the approach used in this section. Doing so allows for a richer exploration of the international political dynamics of non-EU countries' approaches to IFRS, which follows.

\section{Junior allies: the case of Canada}

\subsection{The economic rationale for globalizing Canadian accounting standards}

In January 2006, the Accounting Standards Board (AcSB) of Canada announced that it would initiate a formal process of converging Canadian accounting standards with those of the IASB so that from January 2011, Canadian companies would effectively be reporting under IFRS (CICA, 2006). The decision was a major commitment by Canada-one of the world's largest industrialized economies - to the IASB and its standards. Of particular note was Canada's decision to embrace IFRS wholeheartedly, i.e., without exceptions or limitations. Speaking of the decision, Paul Cherry, the then head of the AcSB noted (Ramanna and Cheng, 2009, p. 7), "Once you say change, shades of gray don't matter a whole lot." The timing of Canada's commitment - shortly after EU-listed companies began using IFRS-based standards, but before most major nonEuropean countries had made a similar commitment - was significant because it signaled an endorsement of the international accounting standards when their future remained uncertain. 
Also noteworthy in Canada's commitment to IFRS was its decision to forgo the accounting standards of its closest neighbor and largest trade and investment partner, the United States. Throughout the process that led up to the AcSB's January 2006 decision, U.S. GAAP had been a serious contender as Canada looked for a globally relevant alternative to its domestic standards (Canadian companies cross-listed in the United States were permitted to use U.S. GAAP for domestic reporting).

Canada's decision to globalize its accounting regime was born of domestic concerns that Canada did not have the scale to support its own unique accounting regulatory regime. Speaking on this issue Mr. Cherry noted (Ramanna and Cheng, 2009 , p. 7), "Our decision is based very much on what we think is the economic reality of the moment and foreseeable future. Canadian markets are, if you are being charitable, about $3 \%$ of the global marketplace. It has become increasingly difficult to make foreign investors comfortable, in the sense of understanding, the Canadian accounting system that we have in place. It is very expensive to educate others. The choices are simple: it's either U.S. GAAP or international standards."

The Canadian economy in 2005 was heavily reliant on foreign trade, which accounted for almost three quarters of the country's total gross domestic product (GDP). This represented a significant increase from the early 1990s, when foreign trade represented about half of GDP. The growing reliance on trade underscored a broader trend towards an increasingly globalized Canadian economy. For example, Canada's capital markets were in 2005 also highly internationalized, with high levels of foreign direct investment (representing more than $30 \%$ of GDP) and foreign portfolio investment (about $37 \%$ of GDP). ${ }^{17}$

The United States was Canada's largest trade and investment partner, accounting for roughly $84 \%$ of its total exports, $56 \%$ of its total imports, and almost two-thirds of total foreign portfolio investment in 2005. And although Canada's dependence on the United States had been decreasing in recent years (largely due to growing commerce with the EU and China), Canada's U.S.reliance remained overwhelming.

Given America's significant role in the Canadian economy, the option to embrace U.S. GAAP as a global alternative to Canadian GAAP was popular in some quarters. For example, several important players in the Canadian oil and gas industry - one of Canada's largest industries - actively lobbied for U.S. GAAP adoption through 2005 (e.g., Ramanna and Cheng, 2009). ${ }^{18}$ In fact, since the early 1990s the AcSB had worked to keep Canadian GAAP aligned with U.S. GAAP to the extent possible, so the full adoption of U.S. GAAP seemed a logical next step to these players.

\footnotetext{
${ }^{17}$ Data compiled from the International Monetary Fund, Statistics Canada, and the World Bank.

${ }^{18}$ Several of the largest Canadian oil and gas companies are subsidiaries of U.S. counterparts.
} 
Among those arguing against U.S. GAAP were the global auditing firms. A comment letter on the issue from Deloitte summarized this opposition (Ramanna and Cheng, 2009, p. 16): “...efforts to harmonize [Canadian GAAP] with the U.S. would continue to produce standards of increasing complexity... Such a path is not likely in the best interest of Canadian capital markets and is certainly not in the best interest of Canadian non-public companies. Accordingly, we support the exploration of a different model: one that permits those who wish to use U.S. GAAP [the option] to do so, [and] the adoption of IFRS as Canadian GAAP..." Another argument against U.S. GAAP adoption in Canada was the ongoing harmonization project between the U.S. Financial Accounting Standards Board (FASB) and the IASB; although it was not clear that the United States would ever fully adopt IFRS, the existence of a harmonization project suggested that the differences between American and international standards would be actively addressed. Moreover, unlike with the IASB, which had been working to solicit Canadian adoption of IFRS, there was no similar attempt on part of the U.S. standard-setting establishment, nor was there a practical procedure in place for Canadian interests to be represented in the political process of U.S. GAAP. Surveying the economic conditions and political climate in Canada in 2005 does not yield a clear prediction on Canada's decision to adopt IFRS over U.S. GAAP. Thus, in the following subsection, I explore some additional hypotheses, in particular those based on cultural sentiments, as an explanation for the decision.

\subsection{Cultural explanations for Canada's IFRS adoption}

Canada has a strong system of formalized accounting and corporate governance practices dating back to the early 20th century. The Canadian accounting establishment is generally recognized as being of high quality: for example, a 2005 IMD report ranked Canada as having one of the most highly regarded accounting establishments in the world (see www.worldcompetitiveness.com). These systems have their origins in Canada's status as a former colony and dependency of the British Crown. The early structure of the accounting profession in Canada closely followed British traditions, as they were set up under the guidance of such frameworks as the British Companies Act of 1900 (e.g., Baylin, MacDonald, and Richardson, 1996). The British influence on Canadian corporate

\footnotetext{
${ }^{19}$ The opposition of global auditing firms to U.S. GAAP is not restricted to Canada and not particular to U.S. GAAP, i.e., global auditing firms can be seen as promoting IFRS over local standards in all jurisdictions studied in this paper. There are at least two plausible reasons for this observation: (1) global auditing firms see one worldwide standard (such as IFRS) as lowering operating costs for themselves; (2) global auditing firms have greater relative influence at the IASB than at national standard-setting bodies, because their opposing interests at the IASB are more dispersed. On the latter point, see, for example, Botzem and Quack (2009).
} 
governance practices is also evident: for example, Canadian principles of corporate disclosure were initially developed in compliance with the 1844 British law on joint stock companies (Gray and Kitching, 2005).

The UK also remains closely associated with Canada in areas outside accounting and corporate governance. Canada is a founding member of the British Commonwealth (the 1926 Imperial Commonwealth) and the UK's sovereign is still nominally Canada's head of state. Other evidence of Canada's close association with Britain can be seen in the incorporation of elements of the Union Jack in the flags of several Canadian provinces and in the incorporation of Queen Elizabeth II's image on Canadian legal tender. And, as recently as August 2011, the Canadian government decided to reinstate the "colonial" names for its navy and air force, designating them as "royal" forces in tribute to Elizabeth II's diamond jubilee (e.g., Hopper, 2011). ${ }^{20}$ Generally, then, with the exception of Québec (a former French colony), Canadians are familiar and comfortable with British institutions.

This familiarity with British institutions could have eased Canada through any anxieties over adopting the London-based IASB as its de facto accounting standard setter, particularly at that early stage (2006) when IFRS' future remained unclear. As discussed earlier, the IASB's origins can be traced back to British interests, and Britain, together with the rest of the EU, remains central to the IASB, as a lead underwriter.

In contrast to Canada's relationship with Britain, its relationship with the United States, despite strong economic ties, is more nuanced. While Canada and the Unites States enjoy substantial cultural exchange and share many substantive practices (including a Common Law tradition), several commentators have noted that the power asymmetry between Canada and its much larger neighbor to the south has engendered a Canadian national "inferiority complex" vis-à-vis the United States. Moreover, acknowledgment of this inferiority complex is both longstanding (dating at least to the 1940s) and public (e.g., Denison, 1949; CBC News, 2010). In a widely cited tongue-in-cheek remark on the U.S.-Canada relationship, former Prime Minister Pierre Trudeau noted at the Washington Press Club in 1969 (CBC Archives, 1969), "Living next to you is in some ways like sleeping with an elephant. No matter how friendly and even-tempered is the beast, if I can call it that, one is affected by every twitch and grunt."

Thus, despite strong economic reasons for Canada to choose U.S. GAAP over IFRS - and attendant domestic political pressure from some Canadian corporations-cultural factors, in particular the longstanding Anglo-Canadian relationship and Canadian sensitivities over ceding sovereign rights to the United States, could have tipped the scales in favor of IFRS. It is noteworthy to point out,

\footnotetext{
${ }^{20}$ The "royal" prefix had been dropped in the 1960s as part of reorganization and cost-cutting
} efforts. 
however, that some large Canadian companies with cross-listings in U.S. exchanges have chosen to maintain their financial reports in compliance with U.S. GAAP rather than switch to IFRS (e.g., Johnson, 2010). This development suggests that the identity politics that shaped Canada's nationwide response to accounting globalization were insufficient to overcome, in at least some instances, economic incentives at the firm level to report under American standards.

\section{Towards a multipolar IASB: the case of China}

\subsection{China's unique economic motives for IFRS adoption}

Starting in the late 1970 s, a series of reforms undertaken by the Chinese central government transformed that country from a centrally planned socialist economy into an export-driven powerhouse that grew at a $15 \%$ average annual growth rate. As a result of this growth, by 2010 China was the world's second largest economy (behind only the United States). Chinese exports totaled more than \$1.5 trillion that year (making it the world's largest exporter), up from $\$ 195$ billion in $1999 .^{21}$ In 2001, China was accepted into the World Trade Organization (WTO), a sign of its emergence from economic isolationism into one of the world's foremost traders.

And while exports played a central role in the thirty-year story of China's spectacular growth, China's domestic capital markets remained a relative sideshow. This was partly due to the fact that shareholding had only just reemerged in the mid-1980s, as part of government efforts to create greater operating efficiencies at state-owned enterprises. China's two major stock exchanges, located in Shanghai and Shenzhen, had a total market capitalization of less than $\$ 2$ trillion in mid-2009, or only about ten percent of that at the New York Stock Exchange. Large and visible Chinese companies preferred to list or to have a second listing on overseas stock markets (including Hong Kong). As of June 2009, the market capitalization of the 65 Mainland Chinese firms listed on the NYSE was $\$ 1.1$ trillion, or more than half the total market capitalization of China's domestic stock exchanges. ${ }^{22}$

In part to address this deficiency in its domestic capital markets, China, in 2005, announced plans to converge its accounting standards with IFRS. There had been numerous studies tying concerns with China's weak accounting institutions and questionable corporate reporting to the stunted development of its capital markets (e.g., DeFond, Wong, and Li, 1999; Tang, 2000). IFRS adoption was

\footnotetext{
${ }^{21}$ Data from the U.S.-China Business Council.

${ }^{22}$ Data compiled from various sources by Ramanna, Donovan, and Dai (2009).
} 
expected to improve accounting quality. In 2006, China introduced new accounting standards that, with a few important exceptions, were based on IFRS. By 2008, listed companies on China's two major stock exchanges as well as most of the country's largest state-owned enterprises had already begun using the new standards. By 2011, all Chinese companies were expected to adopt them.

The capital-market benefits expected to accrue from IFRS adoption are a common theme behind countries' decisions to embrace the standards. ${ }^{23}$ For example, Canada's decision in this regard, discussed earlier, can be tied to these benefits. The remarkable pace of Chinese adoption of IFRS-based standards suggests, however, that China had additional motives when it accepted international accounting standards. One such motive, unique but critically important to export-driven China, is that country's bedevilment in international anti-dumping lawsuits.

Exporters from low manufacturing-cost locations, such as China, are sometimes litigated in the WTO for "dumping" their products in markets where manufacturing costs are higher. These anti-dumping lawsuits, usually brought by governments of destination markets, generally allege that the exporter is selling its products in a destination market at below cost (to establish a presence in that market). To contest an anti-dumping lawsuit, the exporter must show evidence of its "true" cost. Such evidence is particularly difficult for Chinese manufacturers to provide because, per China's WTO accession protocol, the country is classified as a "non-market economy," and as such, cost data from Chinese companies is considered unreliable in international litigation (WTO, 2001, pp. 8-9). Under these circumstances, anti-dumping lawsuits may be adjudicated using cost data from "surrogate" manufacturers in another country: common surrogates are companies from India, Indonesia, and even the United States (p. 9), countries that are generally uncompetitive vis-à-vis China in the worldwide manufacturing export arena. As a result of these conventions, China's success in contesting antidumping lawsuits is unimpressive. ${ }^{24}$

China's WTO accession protocol allows for exceptions to the surrogate rule in anti-dumping litigation if the litigated exporter can show that "market economy conditions" apply in manufacturing (WTO, 2001, p. 9). As part of establishing market economy conditions, the litigated exporter is generally required to provide audited financial statements prepared "in line with international accounting standards," i.e. IFRS (e.g., EC, 2009, p. 55). Thus, compliance with IFRS can provide a significant advantage to Chinese exporters, and in turn, the Chinese economy (from 1995 to 2008, over 20 percent of all antidumping measures worldwide were targeted at China). In fact, since China has

${ }^{23}$ For evidence on such benefits see, for example, Armstrong, Barth, Jagolinzer, and Riedl (2010).

${ }^{24}$ See, for example, the World Trade Organization's statistics on anti-dumping initiations at: http://www.wto.org/english/tratop_e/adp_e/adp_e.htm\#statistics. 
adopted IFRS-based standards, there have been several successful cases of Chinese companies qualifying for market economy treatment on the basis of providing internationally compliant financials: in one case involving transport equipment, the winning exporter was able to reduce import tariffs by nearly $40 \%$ $(\mathrm{EC}, 2005$, p. 7$) .^{25}$

\subsection{The international political economy of China and the IASB}

The considerable anti-dumping benefits from IFRS adoption that can accrue to China's export-driven economy suggest that convergence with international accounting standards is a major priority for the country. However, as discussed earlier, the origin and development of IFRS can be traced to EU and, in particular, British interests. It is unlikely, therefore, that the IFRS standards coming out of London are fully satisfactory to China. Not surprisingly, China has been careful to tailor IFRS to its needs, excepting certain provisions when crafting its domestic "IFRS-based" standards, and in one particular case, working with the IASB to modify IFRS itself to meet Chinese interests. This subsection details some of these exceptions and discusses ramifications.

The first such exception deals with the reversal of asset impairments, which is generally permissible under IFRS. Chinese accounting standards that predate IFRS harmonization efforts eschewed impairment reversals, much like U.S. GAAP. The policy was justified by the traditional income-statement focus in Chinese financial reporting: Chinese investors pay more attention to the income statement at the expense of the balance sheet (e.g., MOF, 2008), and several formal contracting provisions, including exchange listing and delisting provisions, depend almost entirely on reported profits. Given this history, Chinese regulators were wary about unleashing impairment reversals as part of IFRS harmonization efforts. ${ }^{26}$ Doing so could give companies the means to manipulate profits by opportunistically accelerating and reversing impairments. Accordingly, the IFRSbased Chinese Accounting Standards (CAS) limits impairment reversals, particularly for short-term and intangible assets.

The second IFRS exception in CAS deals with the use of fair-value estimates as a basis for accounting. Fair-value accounting has been one of the cornerstones of IFRS, and the IASB, at least until the 2008-09 financial crisis, was an enthusiastic champion of expanding fair-value use in accounting. China,

\footnotetext{
${ }^{25}$ The United States generally does not allow individual companies from non-market economies to qualify for market economy treatment. A recent attempt by the U.S. government to permit such treatment for Chinese companies met with resistance from U.S. businesses and was unsuccessful (DOC, 2007; ITA, 2007).

${ }^{26}$ See, for example, comments by Shenzhen Stock Exchange officials in Ramanna et al. (2009, pp. $7-8)$.
} 
by contrast, has been more tentative in its commitment to fair values. For example, Biondi and Zhang (2007) through a comparative analysis of IFRS and Chinese standards on business combinations provide evidence that that "leading [Chinese] accounting theorists and Chinese regulatory authorities" favor traditional "matching" principles over fair-value accounting. The argument advanced by some Chinese regulators for this hesitancy is the dominance of manufacturing (rather than financial) assets in the economy. Manufacturing assets do not have readily determinable current-value estimates. Moreover, market prices, when available, are unlikely to represent fundamental value due to China's strict capital controls and weak information-intermediation institutions. Fairvalues, a senior Chinese regulator has argued, if unleashed unbridled, can facilitate misreporting. Accordingly, China has been judicious in permitting companies the use of fair values. Some Chinese regulators have even argued that the fact that fair values play a minimal role in their system is one reason why China did not suffer more seriously during the 2008-2009 financial crisis. ${ }^{27} \mathrm{~A}$ compelling example of China's reluctance on fair-value accounting in found in its decision to permit the historic-cost-based pooling-of-interests method for business combinations (in addition to the fair-value-based purchase method) "despite the prohibition of this method by both the FASB and the IASB" (Baker, Biondi, Zhang, 2010).

The third and perhaps most interesting of the Chinese exceptions to IFRS is not an exception per se. Rather, it details China's success in working with the IASB to tailor the IFRS on related-party transactions to meet Chinese interests. When China signed the IASB convergence statement in 2005, a key issue for the MOF in Beijing had been the IFRS standards on disclosure of related parties. Several of China's largest companies have considerable state ownership, and according to a strict interpretation of the then standard, IAS 24, many state-owned enterprises would have been considered related parties, and their transactions related-party transactions. The extent of disclosure required to satisfy the IFRS standards was simply unworkable for China. For a state-owned company to disclose all its related-party transactions "would require thousands of pages," one Chinese regulator said (quote due to an official at the Shenzhen Stock Exchange, identity withheld, Ramanna et al., 2009, p. 6). Over the course of four years, through 2009, Chinese officials at the MOF worked with the IASB to develop a new standard for related-party disclosures. (See Figure 1 for a timeline of the events leading up to the IASB's modified position on related-party disclosures.) The revised IAS 24, released by the IASB in November 2009, redefines "related parties" to provide a worldwide "partial exemption for government-related entities" (IASB, 2009).

${ }^{27}$ Source: interviews with Shanghai Stock Exchange officials, Ramanna et al. (2009, p. 7). 


\section{Figure 1, IAS 24 Timeline}

Prior to 2003, state-controlled entities were exempt from LAS 24 's related-party disclosure requirements. That exemption was removed in a 2003 revision, which specified that profit-oriented state-controlled entities that use IFRS must disclose transactions with other state-controlled entities.

Feb. 2006: China's MOF and the IASB announce plans to converge Chinese accounting standards with IFRS; the MOF begins issuing CAS.

May 2006: The IASB agrees to begin consultations on clarifying IAS 24 requirements for transactions between entities with significant state ownership.

Feb. 2007: The IASB releases a draft of proposed amendments to IAS 24; the amendments (1) exempt some state-controlled entities from related-party disclosures, and (2) change the definition of a related party; the comment period is limited to 90 days in hopes that the amendment can be in place before the end of the 2007 .

Oct. 2007-Jan. 2008: In IASB discussions on the subject, talks end "in a degree of confusion" after the board determines: "in some jurisdictions including China, the state often nominates one or more board members. This fact alone [seems] to indicate that the state would normally 'participate in the operating and financial decisions' of state-controlled entities and thus would always fail the exemption criteria."

Sep. 2008-Nov. 2008: The IASB formulates a new approach whereby relatedparty transactions of state-controlled entities need not be disclosed, but instead general disclosures about the types and extent of significant transactions would be required.

Jul. 2009: The IASB tentatively approves changes to IAS 24, effective Jan. 1, 2011; plans to issue new standard in Nov. 2009. The changes (1) provide a partial exemption for disclosure by government-related entities, and (2) simplify the definition of a related party.

Nov. 2009: The IASB issues revised version of IAS 24.

Source: IAS Plus, IASB Agenda Project, Deloitte Touche Tohmatsu, www.iasplus.com, accessed November 6, 2009.

The impact of the IAS 24 change cannot be overstated. As noted earlier, the disclosure of related-party transactions is central to maintaining the integrity of the "entity concept," the fundamental idea in accounting that an enterprise's financials are its own. That a country with significant state ownership of industry 
was able to redefine worldwide accounting standards on an issue that is so central to accounting is indicative of China's growing power in international standard setting. The incident can be a harbinger of a growing role for power politics in IFRS standard setting as the world grows increasingly multipolar. On this point, note that China's strong central government allows the country to speak with one voice when advocating for itself in international forums such as the IASB. Other emerging-market countries such as India are less likely to be successful in international power politics, as the following section discusses.

The IFRS exceptions in CAS have created, in some circumstances, difficulties for China's exporters in anti-dumping litigation. For example, in a recent case involving a Chinese fine-paper manufacturer litigated in the EU, the EC ruled against the company despite it having demonstrated on paper "market economy conditions" (including providing audited financials in accordance with CAS). As part of its justification for the ruling, the EC noted differences between IFRS and CAS, and expressed skepticism about China's "claimed equivalence" between the standards (EC, 2010, p. 12). Decisions such as this are likely to rouse China into adopting a more active role at the IASB, so that it can reduce the IFRS exceptions it currently carves out in CAS to meet local interests. ${ }^{28}$

\section{Bigger fish from smaller ponds: the case of Tata Steel in India}

\subsection{Accounting and globalization at Tata Steel}

This subsection describes a critical accounting challenge faced by Tata Steel, one of India's largest and most international companies, as it embarks on an ambitious phase of globalization. The Tata Steel experience provides an example of the complexities that can emerge as business operations, accounting standards, and national economic policy globalize at different paces. The following subsection explores the implications of the Tata experience for the calculus of IFRS in India and other countries with similar or less international power.

Tata Steel, described by Indian prime minister Manmohan Singh as (PIB, 2008) "the unique temple of modern India," is one of India's oldest, largest, and most respected companies. Its history, dating to the $1800 \mathrm{~s}$, is tied to the industrialization of India itself, and as such, the company and its parent, Tata Group, enjoy a near exalted status in the Subcontinent. Over the past twenty years, the company has been globalizing aggressively, in part to maintain its competitive position given the liberalization of India's economy. In 2007, Tata Steel acquired UK-based Corus Steel for $\$ 12.1$ billion, in what was then the

\footnotetext{
${ }^{28}$ A less likely scenario is that China avoids creating domestic carve-outs to IFRS.
} 
largest acquisition by an Indian company. The Corus deal catapulted Tata Steel from ranking as the world's 56th largest steelmaker to a place among the top ten (e.g., Moneycontrol, 2007).

Tata Steel funded the Corus acquisition in part through a $\$ 6.2$ billion loan issued by its UK subsidiary. It planned to service the debt through the cash flows of its European operations, which transacted largely in euros. Thus, as part of a hedging strategy (to hedge against foreign-currency risk), Tata Steel denominated the bulk of the debt in euros, an operational hedge (Tata Steel, 2008) ${ }^{29}$ However, Tata Steel's consolidated financials, prepared under a version of Indian Generally Accepted Accounting Principles (IGAAP) that was harmonizing with IFRS, could not recognize the operational hedge. IGAAP, like IFRS, mandated that foreign currency loans be translated into an entity's functional (home) currency for reporting purposes. Accordingly, the Corus loan was expressed in Indian rupees in Tata Steel's consolidated financial statements. With the onset of the financial crisis in 2008-09 and the subsequent appreciation of the euro against the rupee, this accounting treatment had led to the loan amount increasing by $\$ 630$ million on Tata Steel's balance sheet (a portion of this increase was amortized in Tata Steel's income statement for the year). $\$ 630$ million represented about $6.4 \%$ of Tata Steel's net debt for the year ending 2009, and about $64 \%$ of its net income.

The IFRS requirement to translate foreign debt into a reporting entity's home currency is less troubling to U.S. and European companies that can effectively avoid the requirement by raising home-currency-denominated debt on world markets. But Tata Steel, as an Indian multinational, finds it difficult to raise rupee-denominated debt abroad because the Indian rupee, due to governmentimposed capital controls, is not freely available overseas. The translation requirement presents Tata Steel with difficult options. It can: (1) switch the entire company's functional currency to euros, but that will expose the Indian operations to currency fluctuations; (2) ignore the translation impact and hope equity and debt investors do the same, but this approach does not help address covenants that might be triggered by the currency fluctuations; (3) engage in relatively costly lobbying with the IASB; (4) lobby Indian standard setters to create an IFRS exception in IGAAP for situations such as this.

Options (1) and (2) are unlikely to be economically viable for Tata Steel. Moreover, the company, as one of India's largest firms, has a history of leadership in guiding corporate regulation, including accounting standards, within India (see,

\footnotetext{
${ }^{29}$ Hedging in corporations refers to the practice of lowering firm exposure to uncertain events such as fluctuations in exchange rates, interest rates, and commodity prices. Hedging strategies can broadly be thought of as "operational" or "financial." Operational hedges lower risks by restructuring real transactions (such as in the Tata Steel case where the loan was restructured as a euro-denominated loan). Financial hedges do not alter real transactions; they usually involve the purchase and sale of derivative instruments as offsets to the real risks.
} 
for example, the description of Tata Steel's successful attempt at changing accounting standards for employee severances in Ramanna and Tahilyani, 2010, p. 3). Thus, options (3) and (4) are likely to be more palatable to the company. With option (3), however, Tata Steel is likely to run up against several morepowerful interests, such as EU, U.S., and Chinese interests (the latter benefiting from a dollar-fixed exchange rate), and is thus unlikely to prevail. This process of elimination leaves the company with option (4) as the most practicable course of action. The implications of option (4) for the calculus of IFRS harmonization in India are the focus of the next subsection.

\subsection{The calculus of IFRS in India}

Since at least the early 2000s, India's Accounting Standards Board (ASB) has issued accounting standards that are based on IFRS. When formulating standards, the ASB departs from IFRS only in unavoidable cases, usually when conflicts exist with the legal or regulatory framework prevailing in the country. In 2007, India announced that it would go a step further and achieve formal "convergence" with IFRS by 2011 (IASB, 2007). As in the case of Canada, the large global auditing firms supported this decision. Kumar Dasgupta, a partner at PriceWaterhouseCoopers in India, explained the rationale (Ramanna and Tahilyani, 2010, p. 6): "There is anecdotal evidence from our clients that they do get easier access to cross-border finance if they are using IFRS because on occasion the credibility of Indian GAAP as a standalone measure can be questioned."

Although India's 2008 convergence roadmap envisioned that the country's largest companies would be IFRS compliant by April 2011, the goal remained unmet as the date passed. In the past two years, India has had to postpone its convergence deadlines twice (Tiwari and Sanyal, 2010; MCA, 2011). In part, the delays can be attributed to fundamental differences between IFRS and IGAAP that are difficult to reconcile. One such difference is in the area of depreciation. Under IGAAP, depreciation is either at rates based on an asset's estimated useful life or on statutory depreciation rates that the country's Companies Act prescribes, whichever is higher. The effect is a mandatory minimum depreciation rate. IFRS, in contrast, has no concept of a minimum rate of depreciation: depreciation is based on the number of years an entity is expected to use the asset. The conservatism introduced by IGAAP in this and other contexts is often well regarded by domestic investors. Sarju Simaria, a senior executive at Edelweiss Capital, a large financial services company, noted (Ramanna and Tahilyani, 2010, pp. 5-6): "On some policies, we are better placed in terms of what is being proposed by IFRS, and one of them is conservatism... Conservatism is a good policy particularly in an environment where you don't have a mature market..." 
The delays in implementing India's convergence timetable can also be attributed to political concerns about the nature and priorities of IFRS. On the subject of accounting for foreign currency translations, Y. H. Malegam, chairman of India's National Advisory Committee on Accounting Standards noted (Ramanna and Tahilyani, 2010, p. 7), "If the U.S. borrows money abroad, often it will denominate that borrowing in dollars, therefore eliminating the translation impact. However, if India borrows money abroad they have to denominate it in sterling, [in] dollars, or in euros, leading to a translation impact and creating unnecessary volatility. An [Indian] company, which has dollar borrowings, and dollar earnings, can repay the loan from its dollar earnings; the exchange rate during the period of the loan [should be] irrelevant." Recognizing that the political interests shaping IFRS do not always line up with Indian interests, C.B. Bhave, India's chief securities regulator noted (Ramanna and Tahilyani, 2010, p. 8), "The path [I see] is towards convergence and we must go down the path in a gradual manner. We speak English, but we speak Indian English. We understand British English and American English but we still prefer to speak Indian English.”

An alternative approach to "gradual" convergence for countries like India is to adopt China's policy of engaging the IASB directly in shaping IFRS, particularly in areas of national interest. Historically though, India has adopted a passive mindset to international affairs rooted in a "soft power" identity (e.g., Khanna, 2007, p. 252). This policy can be traced to India's first prime minister, Jawaharlal Nehru, who advocated a cold-war foreign policy based on "nonalignment," "non-aggression, non-intervention, mutual benefit and equality, and peaceful co-existence" (see, for example, the Sino-India Treaty of 1954, UNO, 1958, p. 70). ${ }^{30}$ Moreover, even if India decides to engage the IASB, it is unclear whether it has the political power necessary to steer policy at an international level. India, despite substantial economic growth over the past decade, is still generally considered well behind China in international standings (e.g., The Economist, 2010). Moreover, unlike in China where the MOF serves as the nodal and ultimate decision authority on accounting matters (e.g., World Bank, 2009), India's accounting landscape is dotted with an alphabet soup of regulatory agencies, professional organizations, think tanks, and industry groups (see: Ramanna and Tahilyani, 2010, for a description of these bodies; and Figure 2 for a list of regulatory/ statutory agencies with input into IGAAP): The high coordination costs and differing interests of these organizations make it difficult for an Indian lobbying position to have unified domestic support on the international stage.

\footnotetext{
${ }^{30}$ China was also an official signatory to this policy of passivity; but, as historians and political scientists have noted, China has in practice adopted a more assertive stance in foreign policy (e.g., Kissinger, 2011).
} 


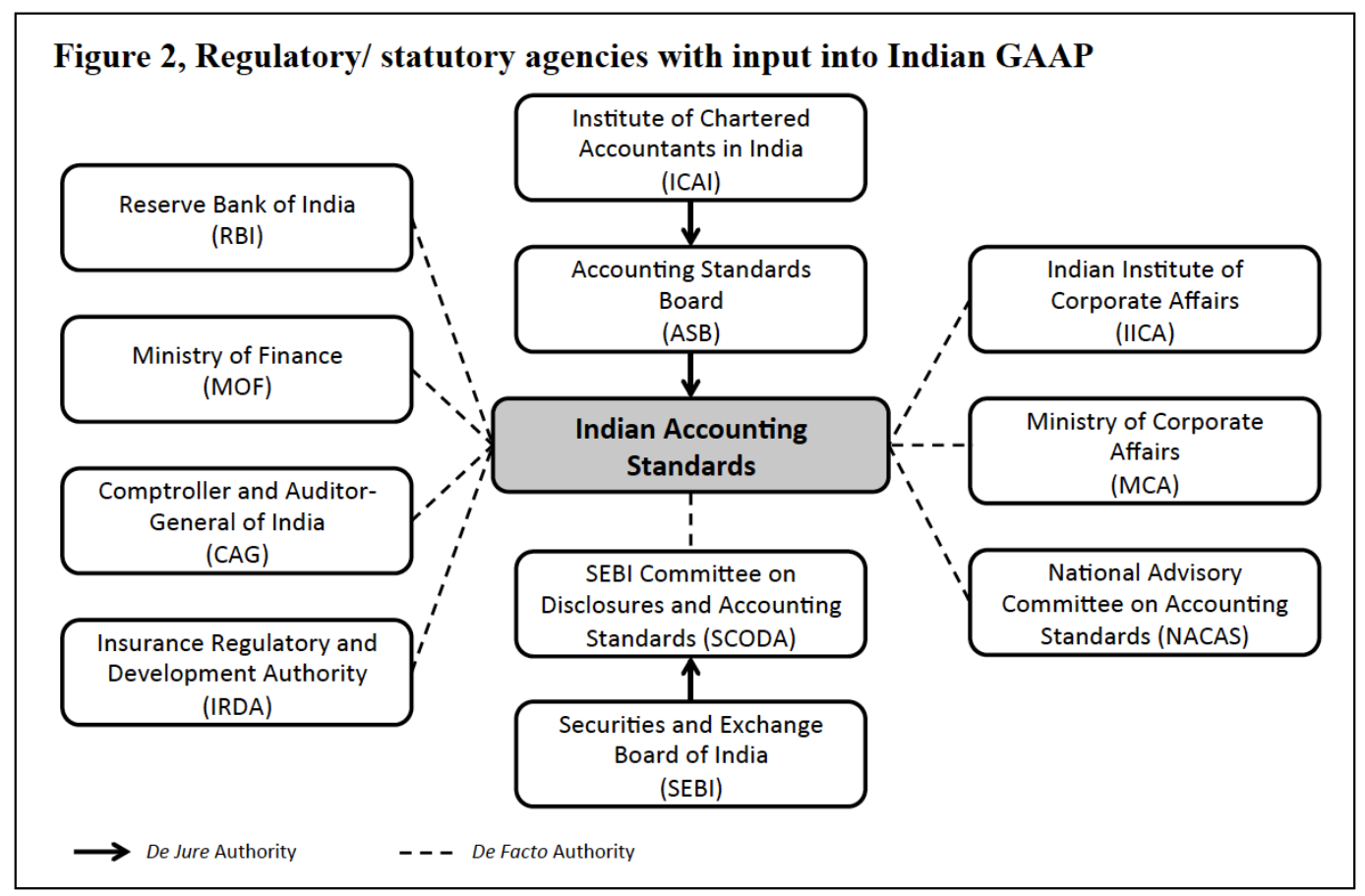

To summarize, while there is a compelling economic argument for a country like India to adopt IFRS, differences between the political priorities of the IASB and those of India can delay convergence. One solution to this situation is for the country to engage the IASB more directly in standard-setting discussions, but it is unclear whether India has the power necessary to break through the established interest groups at the IASB.

Another potential solution to the situation described above is crosscountry regional alliances or coalitions, either by countries themselves or by companies with similar concerns. At the country level, such coalitions are already beginning to form: the Asia-Oceania Standard Setters Group (AOSSG) being a prominent example. The AOSSG was established in 2009 and is composed of accounting standard setters from countries in the region. ${ }^{31}$ Ostensibly, the group exists to "leverage the knowledge" of its member states on financial reporting issues and "share experiences on implementation" of IFRS across the region (AOSSG, 2011). On a day-to-day basis, the AOSSG operates through several working groups focused on substantive areas, such as financial instruments, fair values, and revenue, with member states taking the lead on one or more working

${ }^{31}$ As of August 2012, the member states of the AOSSG are: Australia, Brunei, Cambodia, China, Dubai, Hong Kong, India, Indonesia, Iraq, Japan, Kazakhstan, Korea, Macao, Malaysia, Mongolia, Nepal, New Zealand, Pakistan, Philippines, Saudi Arabia, Singapore, Sri Lanka, Thailand, Uzbekistan, and Vietnam. 
groups. The working groups "monitor" the IASB, issue comment letters on IASB exposure drafts, and draw the IASB's attention to AOSSG positions. ${ }^{32}$ Little is known about the political economy of the AOSSG; the process of forming the working groups and appointing their leaders; the effectiveness of the working groups in managing the diverse interests of their constituencies and in shaping IASB policy. This is likely to be a fruitful area for further study.

\section{The international politics of IFRS harmonization}

\subsection{An inductive framework}

Sections 2 through 5 all sketch out important elements that contribute to an understanding of the international political dynamics of countries' IFRS harmonization decisions. Section 2 describes the central role of the EU and, in particular, British interests in the establishment and operation, thus far, of the IASB. The IASB can trace its origins to British-led international collaborations on accounting matters. These antecedent organizations were more consultative than legislative, and thus, did not expressly produce accounting standards for international consumption. However, they did lay the groundwork upon which the IASB was constituted. A key event in the conception of the IASB was the EU's desire to have one region-wide set of accounting standards; the IASB allowed the EU to project that vision worldwide. Since its establishment, the IASB has remained close to the EU, the latter's underwriting being an important element in the legitimacy and growth of IFRS across the globe. But the board's closeness to the EU has come with strings attached: a recent example involved the IASB suspending an evolving reputation for due process in acquiescence to European banking interests during 2008-09 financial crisis. This play of events led at least one British parliamentarian to refer to the board as "spineless" (Leone, 2008).

Section 3 describes the seemingly perplexing decision of Canada to adopt IFRS over U.S. GAAP. Canada in 2005, in the face of an increasingly internationalized economy, contemplated supplanting its own domestic GAAP for that of either its closest neighbor or the IASB. There were, and continue to be, strong economic arguments for Canadian adoption of U.S. GAAP: the United States is Canada's largest investor and trade partner. Nevertheless, Canada chose to converge with IFRS. The decision can be explained by contrasting Canada's relationships with Europe and the United States. The territory that constitutes Canada emerged from British and French colonies in North America, and Canadian cultural ties to these countries (particularly Britain) remain

\footnotetext{
${ }^{32}$ See www.aossg.org.
} 
substantial - the dominant cultural traditions in Canada being shaped by British settlers. By contrast, Canada enjoys a nuanced relationship with the United States; although the two countries have many similarities, the vastly greater size of the United States has resulted in the Canadian position being sometimes described in the popular culture as marred by an "inferiority complex." These juxtaposing associations highlight the broader role that a nation's cultural comfort with the dominant authority at the IASB (currently the EU) can play in its decision to adopt IFRS.

China's process of convergence with IASB standards highlights another dimension in the international politics of IFRS harmonization. Section 4 begins with a description of the unique economic pressures on Chinese exporters to present internationally accepted financials: these exporters are routinely subject to anti-dumping litigation in their destination markets. By harmonizing with IFRS, China's MOF hoped to create legitimacy around its financials in international litigation. But IFRS, shaped to function in markets characterized by well-defined monitoring and information processing institutions (such as in Europe or Canada, e.g., Ball, 2006), is not particularly well suited to China's emerging market conditions. Accounting technologies such as fair value and impairment reversals are seen by China's MOF as perilous. Moreover, the extensive disclosure on related-party transactions required under IFRS posed a compliance complexity for China's large and interconnected state-owned enterprises, which typify that country's economy. To meet the economic demands that drew it towards IFRS, but still maintain standards that reflect China's domestic conditions, the MOF adopted a dual process of excepting certain IFRS standards from Chinese GAAP and working with the IASB to move IFRS itself closer to Chinese interests. China is likely one of the few non-European powers to currently enjoy the international standing to pursue the latter element of this strategy; but the notion of IFRS being shaped by a multilateral political dynamic is one with important implications for the development and growth of the standards.

Just as elements in IFRS are ill suited to Chinese markets, Indian companies suffer from some discordance between IFRS as issued by the IASB and international standards that would be optimized to their domestic conditions. In Section 5, I lay out some accounting challenges faced by Tata Steel, one of India's largest companies, as it embarks on an ambitious program of globalization; the challenges can be traced to the differential pace in globalization of India's accounting standards, its other commercial regulatory provisions, and Tata Steel's own operations. The situation leaves Tata Steel in a position where it must either lobby the IASB to amend IFRS itself or seek exemptions from IFRS in Indian standards. Both approaches are costly on a number of dimensions, including the coordination costs of lobbying and the cost of differentiating standards. The costs suggest that there is some ambiguity about the usefulness of 
IFRS to companies such as Tata and countries such as India. Whether crosscountry regional alliances among companies or countries can be used to defray these costs remains an open question.

Figure 3, The influence of international politics on countries' IFRS harmonization strategies

Predicted national strategy on IFRS harmonization

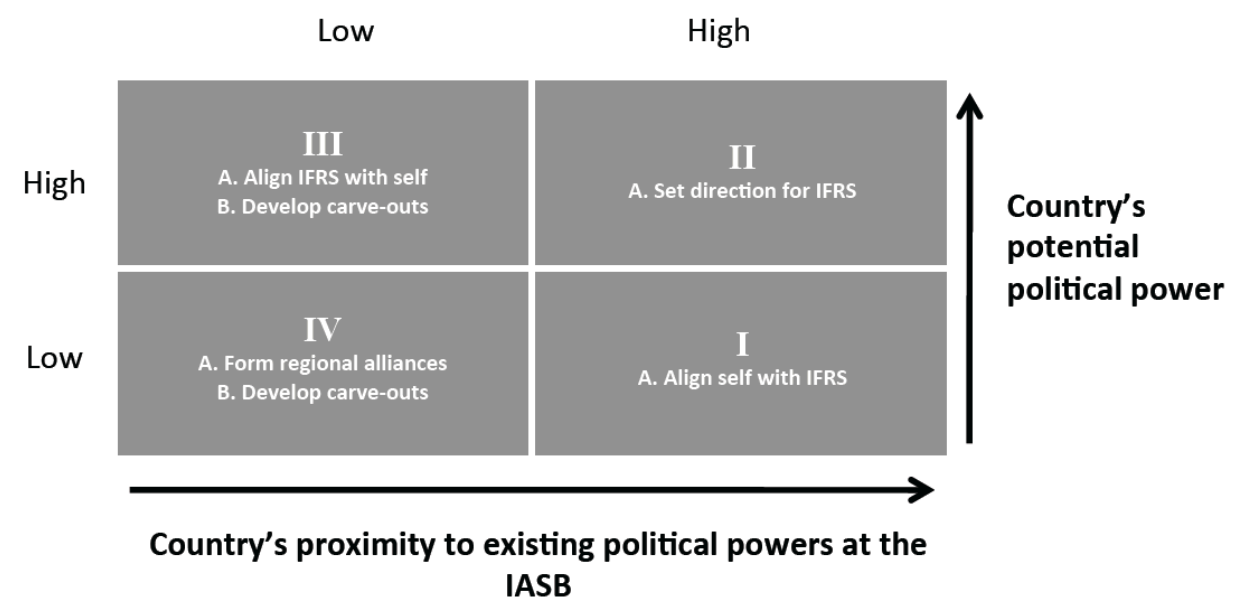

From the various field studies abstracted above, I inductively develop a framework to analyze how international politics can shape countries' strategies on IFRS harmonization. The framework is shown as a $2 \times 2$ matrix in Figure 3. In the matrix, the $\mathrm{x}$-axis represents a country's proximity to the existing political powers at the IASB, where "proximity" is essentially a distance metric on a culture dimension. Here, "culture" can be understood as "beliefs and preferences that vary systematically across [entities] separated by space (either geographic or social) or time" (Fernández, 2008).

The IASB, as it is currently set up, is strongly influenced by EU and, in particular, British interests; thus, Canada, with its Anglo-French roots, would score high on the $\mathrm{x}$-axis dimension. ${ }^{33}$ Note that the dimension is "proximity to the

\footnotetext{
${ }^{33}$ The argument that Canada scores high on the $\mathrm{x}$-axis dimension is based on its cultural proximity to Europe and, in particular, Britain, as argued in Section 3. To objectively verify this claim requires an ex-ante metric of culture. There have been numerous attempts to quantify culture in accounting and elsewhere (e.g., Baskerville, 2003); Hofstede (2001) is one such attempt. Based on
} 
exiting powers at the IASB,' not 'relative proximity to the UK/EU over the United States,' so scoring Canada highly on the X-axis does not take away from its relation with the United States. More generally, a country can have close proximity to both the UK and the United States (in fact, this is likely given that these two countries are themselves close), but this feature is not mutually exclusive to being scored highly on the x-axis dimension.

The matrix's y-axis represents a country's potential political power, i.e., its ability to shape decisions at the IASB. China, as illustrated by the example of related-party transactions described above, would score high on this dimension, as would the larger EU member states, such as France, Germany, and the UK. In the matrix, the benefits to IFRS adoption are held constant. The benefits include those discussed in the context of Canada, China, and India; in particular, the potential to lower translation costs to foreign financial-statement users by having a common worldwide accounting standard.

The lower right box in the matrix (Quadrant I) represents countries with high proximity to the existing IASB political powers, but low potential political power. Besides Canada, I expect countries such as Australia and New Zealand can be classified as Quadrant I countries. These countries enjoy close cultural ties to the extant powers at the IASB, i.e., the EU and particularly Britain, but are not themselves likely to decidedly shape IFRS policy. Assuming translation benefits to IFRS adoption, the strategy among this group is to align themselves with the existing IASB powers (i.e., Quadrant II countries). By doing so, such countries are likely to reap the benefits of IFRS adoption, while being reasonably ensured that IFRS standards continue to meet the economic and political conditions of their domestic markets.

Countries in the upper right box (Quadrant II) score high on both dimensions, and thus, have the greatest incentives to harmonize with IFRS. As described in Section 2, these countries are expected to take a leading role in setting and legitimizing IFRS. An interesting question is whether countries currently in this quadrant can continue to maintain their influence over the IASB in the face of competing pressure from other, larger countries such as China and from international coalitions such as the AOSSG. The EU itself (through its collective embrace of IFRS) provides an important vehicle for these countries to exercise influence over the IASB, but as discussed later, there are signs of greater discordance within the EU vis-à-vis accounting policy, particularly in the wake of the 2008-09 financial crisis. On a related point, the United States, which can also

the first four dimensions of the Hofstede score, Canada compares with the UK and the EU as follows: 'Power Distance' or PDI (39, 35, 49), 'Individualism versus Collectivism' or IDV (80, $89,60)$, 'Masculinity versus Femininity' or MAS $(52,66,44)$, 'Uncertainty Avoidance' or UAI $(48,35,72)$. The world averages are: PDI (58), IDV (45), MAS (49), UAI (67). For full details, see http://geert-hofstede.com/. 
be potentially classified as a Quadrant II country, has not formally committed to IFRS adoption; rather, the United States enjoys a unique role of hyper-influential outsider at the IASB. ${ }^{34}$ The reasons for the U.S.'s non-adoption status are too numerous to explore fully in this paper, but in the following sub-section I briefly address the subject. ${ }^{35}$

The upper left box (Quadrant III) represents countries with low proximity to the existing IASB political powers, but high potential political power. China is the archetype of such a country. Another possible candidate for this quadrant is Japan. Although, to my knowledge, Japan has not been directly involved in shaping a particular IFRS standard to meet its domestic interests, ${ }^{36}$ Japan has demonstrated its ability to do so in another standard-setting arena: defining banks' capital adequacy requirements under Basel III. Hawkins, Ramanna, Sato, and Yamazaki (2011) chronicle Japan's active lobbying during the negotiations over Basel III, in particular, to include deferred tax assets in Basel III's definition of Tier 1 capital: without such inclusion, most of the major Japanese banks would fail Basel III's minimum capital standards. Countries in Quadrant III have markets that are institutionally different from those in the EU; thus, as seen in the section on China, IASB standards that predominantly reflect European conditions are unlikely to be satisfactory to such countries. One natural response for these countries is to develop expedient IFRS carve-outs, as China has in the case of fair values and impairment reversals. In addition, such countries are also likely to gradually exercise their ability to shape IFRS, so as to bring it closer to their interests. The exercise of this power is likely to result in a more multilateral IASB; but its implications for the quality of IFRS are less clear (see also Section 7).

Finally, for countries in the lower left box (Quadrant IV), i.e., those scoring low on both dimensions, the political strategy on harmonization is least clear. India has been presented as the case of such a country, scoring low on the yaxis in part because it as yet lacks the political power of China to shape IFRS and in part because its domestic political interests are not as well aligned as China's to speak with a strong voice internationally. But some further explanation is required on why India is scored low on the x-axis, particularly since, like Canada, India is a former British colony. Indeed it is not unreasonable to argue that India has some

\footnotetext{
${ }^{34}$ As of 2011, over a fifth of the IASB's board and trustees were American.

${ }^{35}$ Simmons (2001, pp. 609-611) offers a theory to explain U.S. resistance on global accounting harmonization that is grounded in the proposition that the U.S. experiences "low negative externalities" from such resistance, while other nations have "high incentives to emulate" U.S. GAAP.

${ }^{36}$ Former IASB chairman David Tweedie acknowledged the role of the Japanese accounting standard-setting body in shaping IFRS, calling the body "very influential in the current debates on new IFRSs" (ASBJ, 2011). I thank an anonymous reviewer for bringing this quote to my attention.
} 
proximity to the UK, given the long colonial history and the fact that Indian legal, accounting, and company procedures in place at that country's independence were based in part on British equivalents. But since 1947, India has made significant departures in the British traditions it had inherited, even embarking in a 40-year experiment in socialism that put it close to the Soviet Union during much of the Cold War. Moreover, while Indian corporate procedures are somewhat based on British traditions, India has its own indigenous legal and accounting practices that go back thousands of years (e.g., a discussion of accounting practices can be found in Kautilya's Arthashastra, c. 300 BC) And unlike Canada, India is not a nation whose dominant cultural traditions are shaped by European immigrants. ${ }^{37}$

Quadrant IV countries, like Quadrant III countries, find IFRS not particularly well suited to their domestic conditions. But such countries are unlikely to be able to individually advance their domestic interests at the IASB, so harmonizing with IFRS can bring real costs in the intermediate run. The recent development of regional standard-setting coalitions in Asia suggests one possible solution to the weak-power problem. Whether this solution will be effective in practice, especially given the costs of coordination, remains an empirical question for future research.

In considering the empirical validity of the predictions from the framework above, recall the caveats discussed in the introduction. The "partial equilibrium" nature of the analysis above suggests several other dimensions might affect countries' IFRS harmonization decisions. One such dimension is the perceived network benefits to IFRS harmonization. Ramanna and Sletten (2011) study the importance of countries' perceptions that they will lower the transactions costs to foreign users of financial statements by adopting IFRS. For a given country, the authors expect these perceived benefits to increase as more of the country's trade partners adopt IFRS; they refer to perceived benefits so measured as the network effects of IFRS. The authors find that network effects are statistically and economically significant determinants of IFRS adoption after controlling for alternative explanations. Of particular interest to the framework in this paper, the authors find that perceived network benefits are more significant in the IFRS harmonization decisions of smaller countries. These countries are more likely to be classified as Quadrant IV countries in Figure 3. Thus, in a more general equilibrium analysis, Quadrant IV countries may be seen as adopting IFRS contrary to the predictions above, but this decision can be attributed to perceived network benefits. ${ }^{38}$ Notwithstanding such caveats, it is useful to understand how international political considerations can come to affect

\footnotetext{
${ }^{37}$ More quantifiably, the first four dimensions of the Hofstede score on India and the UK are as follows: PDI $(77,35)$, IDV $(48,89)$, MAS $(56,66)$, UAI $(40,35)$. The world averages are: PDI (58), IDV (45), MAS (49), UAI (67). See http://geert-hofstede.com/.

${ }^{38}$ In this sense, perceived network benefits can be viewed as a third dimension in Figure 3.
} 
countries' IFRS harmonization decisions: as discussed in Section 7, the potential influence of international politics in IFRS has important implications for the IASB and for international accounting more broadly.

\subsection{The special case of the United States}

In this section, I briefly discuss the special case of the United States vis-à-vis IFRS and the IASB. The United States is at once one of the IASB's most powerful constituents and most reluctant endorsers. Relatedly, U.S. adoption of IFRS is likely to both increase the legitimacy of the standards and decrease the incentives for other nations to adopt them (the latter because U.S. adoption is likely to result in IFRS taking on the litigation-proof character currently seen in U.S. GAAP). Adding to these contradictions, IFRS continues to be shaped by American interests (particularly given the convergence efforts between the FASB and IASB since 2002), all while U.S. GAAP remains the only potential alternative to IFRS on the international stage. Below, I expand on these points.

Since its establishment in 2001, the IASB has intended for IFRS to become recognized in the United States. Organizationally, the IASB has been designed to be similar to the FASB. Such similarity, it was believed, would improve the chances of the United States eventually adopting IFRS (Benston et al., 2006, p. 230). Americans also have broad representation across IASB structures: As of late 2010, four of the fifteen board members, five of the twenty trustees, and the foundation's top staffer, its chief operating officer, were all American (e.g., Ramanna, Misztal, and Beyersdorfer, 2011). No other nation enjoys this level of representation on the IASB. It is reasonable to conclude that had the United States adopted IFRS, it would be classified a Quadrant II country. (Relatedly, the survey and empirical evidence in Büthe and Mattli, 2011, are consistent with a central role for U.S. interests in IFRS standard setting.)

A first step toward a U.S. commitment to IFRS was made in 2002, when the FASB and IASB pledged to make their accounting standards "compatible" (Benston et al., 2006, p. 230). From 2002 to 2007, the bodies "converged" on issues such as accounting for changes in accounting standards, accounting for error corrections, and accounting for share-based compensation (e.g., Langmead and Soroosh, 2009). In recognition of the progress achieved, in 2007, the U.S. Securities \& Exchanges Commission (SEC) lifted the requirement for foreign companies listed in the United States to provide U.S. GAAP financials, and allowed their alternative use of IFRS (SEC, 2007). In 2008, the SEC voted for an updated convergence roadmap proposing a switch to a single set of standards for all U.S. companies by 2014, with a final decision scheduled for 2011 (SEC, 2008). Since then, however, the world has endured a major financial crisis that has significantly altered the political economy of U.S. capital markets. Moreover, 
a changed presidential administration and a changed SEC leadership since 2008 mean that prior American commitments to IFRS are less likely to be upheld. Not surprisingly then, in July, 2012, the SEC issued a staff report that effectively delayed the possibility of U.S. adoption of IFRS indefinitely (SEC, 2012).

Beyond immediate political-economic considerations tied to the fallout of the 2008-09 financial crisis, American political reservations on IFRS can be traced to a longstanding popular-cultural belief in American "exceptionalism," a phrase probably attributable to de Tocqueville, who referred to the adolescent nation he scrutinized in his influential 1835 tome as "exceptional" (2004, pp. 517-518). But the sentiment likely traces even further into American history, to the earliest British settlers: John Winthrop, the first governor of the Massachusetts Bay Colony, referred to the community he was to lead in 1630 as a "city upon a hill," a belief since reaffirmed by American presidents as diverse as John Kennedy and Ronald Reagan (e.g., Kennedy, 1961; Reagan, 1989). Relatedly, Thomas Jefferson's inauguration address in 1801 called for "honest friendship with all nations, [but] entangling alliances with none" (Jefferson, 2006). American exceptionalism has manifested itself in international policy on issues as substantial as the U.S.'s rebuff of the League of Nations after World War I to those as parochial as America's refusal to adopt the metric system (together only with Liberia and Myanmar). An ironic and serendipitous byproduct of such exceptionalism, if it does in fact result in an indefinite American holdout to IFRS, is that the FASB can offer some competition in ideas to its London-based counterpart: Several academics have argued that adopting IFRS in the United States could impede innovation in accounting standard-setting, since such an adoption would virtually guarantee the IASB a worldwide monopoly over accounting issues (e.g., Kothari, Ramanna, and Skinner, 2010, and cites therein).

But, as engaging as the idea of U.S. GAAP as an alternative to IFRS may be, it is pertinent to note that the SEC does not seek the adoption of its accounting standards overseas. Moreover, the empirical evidence on the political economy of U.S. GAAP points to the role of domestic interests; I am not aware of any systematic evidence suggesting international interests shaping outcomes in U.S. GAAP. The latter is likely to serve as a disincentive to foreign countries considering adoption of American standards (also see the earlier discussion on Canada).

To summarize, the United States presents a unique case in the study of the international political dynamics of IFRS. The United States is at once a key influence at the IASB (very likely qualifying as a Quadrant II country if it adopted IFRS), but still an outsider in the sense of its ongoing reluctance to commit to the international standards. Thus, the United States is simultaneously regarded as shaping IFRS, while offering, in U.S. GAAP, an alternative to IFRS. 


\section{Discussion}

\subsection{Implications for IFRS-related issues in practice}

The political considerations that can shape IFRS harmonization, as highlighted in the preceding sections, are important for the future of the IASB. As evident from the discussions above, the nature of countries' commitments to IFRS varies considerably with political-economy considerations. A few countries, including Australia and Canada, have adopted IFRS with almost no exceptions. Some other countries require IFRS only for certain segments of the economy (e.g., banks). Still other countries, such as China and India, have engaged in an oftenambiguous process known as IFRS "convergence." Because national standardsetters define the extent of "convergence," two countries that the IASB identifies as IFRS-convergent can have very different standards in practice.

The emergence and growth of convergence-based approaches to IFRS harmonization, especially among larger emerging-market nations such as China and India, raise interesting questions for the future of IFRS. On one hand, convergence-based IFRS harmonization can be viewed as posing a serious threat to the conceptual goal of one global accounting. Advocates of adoption over convergence, represented visibly by the IASB itself and the Big Four audit firms, argue that fully replacing local GAAP with IFRS is the more effective way to ensure international comparability of financial statements (e.g., Sweeney, 2009). Incoming IASB vice-chairman Ian Mackintosh notes (Kranacher, 2010a): "Convergence is [an] impossible dream. You will always find issues where you basically don't agree and where both sides have good reasons for not agreeing. You've just got to make a decision. Fiddling with IFRS [locally] is not the way forward." Convergence champions, on the other hand, stress the need to remain flexible and adjust accounting rules to domestic political economies. They argue that such adaptability of accounting to local needs leads to a better understanding of local business performance. ${ }^{39}$ In addition, convergence is viewed as more politically palatable given concerns about surrendering jurisdictional sovereignty to a Euro-dominated IASB (e.g., Sweeney, 2009). Thus, convergence, with its emphasis on realpolitik, can be seen as a pragmatic solution to the otherwise high political barriers to globalized accounting. Resisting convergence can have the perverse effect of increasing the role of power politics in IFRS standard setting. Without a convergence option, Quadrant III countries may be more likely to engage the IASB to align IFRS with their interests.

\footnotetext{
${ }^{39}$ See, for example, the quotes from several Chinese officials reported in Ramanna et al. (2009).
} 
In addition to the procedural concern illustrated by the convergence versus adoption debate, the financial crisis of 2008-09 has uncovered substantive differences across countries around IFRS. The substantive differences deal largely with fair-value accounting, a practice with which the IASB has been closely identified since its inception. The differences on fair value are suggestive of a fissure within the EU consensus that has underwritten the IASB for the past ten years. The first major dissonance on fair values started in 2003, when the EU prepared to vote on finalizing IFRS adoption. At the time, French and German banking interests protested the mark-to-market character of the IAS 32 and IAS 39 regulations on financial instruments, demanding influence to reshape the proposal (e.g., Parker, 2003). Five EU member states-Belgium, France, Italy, Portugal, and Spain - joined in to express reservations on IAS 39; their most prominent advocate being then French president Jacques Chirac (e.g., Brackney and Witmer, 2005). This pressure was successful in delaying the adoption of both standards in the EU. In the wake of the 2008-09 financial crisis, frictions around fair values in IFRS have intensified. The rules on hedge accounting are one example. On one side are France, Germany, and the European Central Bank who resist the introduction of more mark-to-market principles (e.g., Sanderson, 2009). "Stability is part of the quality of standards," notes Jérôme Haas, head of the French accounting standards body (Jones, 2009). This group considers the 200809 financial crisis to be primarily caused by illiquidity in financial markets, and so views promoting post-crisis stability as paramount. On the other side, the UK, with its traditional faith in capital market institutions, is seen as promoting greater transparency in financial reporting through increased fair-value use (especially for impairment) as a more appropriate post-crisis accounting response (e.g., Chancellor, 2008). A fissure within the EU on an issue as substantive as fair values can open the door for more emerging-market economies to play a defining role at the IASB. As a practical matter, it may result in more Quadrant IV countries (such as India) being reclassified as Quadrant III countries.

A manifestation of this coming reclassification of countries across quadrants can be seen in the results of the IASB's 2010 constitutional review, which included guidelines to ensure a broader international basis for board membership. ${ }^{40}$ Supporters of reform have sometimes criticized the board's Anglocentric orientation. ${ }^{41}$ David Tweedie, himself, has acknowledged this in an interview (Kranacher, 2010b), "Currently on the board are people from South Africa, Australia, the UK, and America; at least half of the board is AngloAmerican, and we [all] account basically the same way." The constitutional

\footnotetext{
${ }^{40}$ Ramanna, Misztal, and Beyersdorfer (2011) discuss the constitutional review in more detail.

${ }^{41}$ For example, across a series of interviews with German accountants, Heidhues and Patel (2011) provide evidence of a German perception of Anglo-centric bias at the IASB. See also, Botzem and Quack (2009).
} 
review has prescribed broader geographic diversity for an enlarged board of 16 by 2012: four members from Europe, four members from North America, four members from the Asia/Oceania region, one member from Africa, one member from South America, and two members appointed from any area subject to maintaining overall geographical balance (IFRS Foundation, 2009). These reforms are likely to reduce the influence of British and European interests at the IASB, which in turn can encourage countries to reassess both their proximity to existing political powers at the IASB and their own potential political power at the IASB. (Note that IASB members are not formally required to represent their home countries' interests while serving on the board.)

Finally, there is the issue of the U.S.'s position on IFRS, a topic briefly addressed in the previous section. As noted earlier, the United States, without formally committing to IFRS, remains influential on the IASB. How, if at all, is the framework developed in this paper affected given the recent SEC staff report rejecting full IFRS adoption in the foreseeable future? Particularly in light of the IASB's organizational reforms discussed above, I expect the U.S.'s relative influence on the IASB to decline. However, even in this case, U.S. participation in the IASB is likely to remain a significant source of legitimacy for IFRS, so it is unlikely that major U.S. interests will be altogether marginalized. (On this point, consider the following comment from IASB founding chairman David Tweedie in Kranacher, 2010b, "We can have international standards, but we will never have global standards without the United States... It would be very difficult for the rest of the world to accept [IFRS] if the United States said, 'We are not going to do this."')

\subsection{Research implications}

Beyond issues in practice, the paper's analysis of international political dynamics in IFRS harmonization raises interesting questions for future academic research. In particular, if international politics plays a significant role in shaping countries' IFRS harmonization strategies, does that make the international standards more or less effective as an institution of global governance? On one hand, a technocratic view of accounting advocates resisting political interference in standard setting decisions (e.g., Barth, 2006). Under this view, a politicized IFRS harmonization process can be indicative of compromised legitimacy of IFRS. ${ }^{42}$ On the other hand, an evolving political-science literature on global governance institutions suggests an active cross-country political dynamic can be important to creating

\footnotetext{
${ }^{42}$ On standard setters' desires to "legitimate" themselves, Young (2003) notes how the FASB engages in "rhetorical strategies" to ensure that its standards are seen (p. 637) "as emergent from a rational process that separates the technical and political rather than as the result of the desires or wants of a particular agent or a process of accommodation."
} 
legitimacy for international organizations (e.g., Buchanan and Keohane, 2006). Under this view, a vibrant role for international politics in IFRS harmonization is an affirmative sign for IFRS. The framework I present here cannot resolve these competing arguments, but it can provide some basis for further work evaluating the effectiveness of international accounting as a conceptual idea. Ultimately, we must learn whether the political process underlying IFRS facilitates the production of economically efficient standards. (This debate transcends international accounting and applies to accounting more generally. In fact, addressing this debate is one of the fundamental objectives of the Convivium: See Biondi, 2011, and Sunder, 2011. Baker et al., 2010, begin to develop a framework to address these questions.)

\section{Conclusion}

Over the 2001-2010 period, about 100 countries have in varying degrees committed themselves to the globalization of accounting through IFRS harmonization. The spread of IFRS worldwide is a complex phenomenon likely involving the understanding of numerous interweaving economic and political forces. In this paper, I offer an analysis of some international political dynamics of IFRS harmonization. While international politics is not the only or even the deciding element in understanding the growth of IFRS, it is likely to be important.

The analysis in this paper is based on field studies of three jurisdictions: Canada, China, and India. Across these jurisdictions, I first describe unique elements of domestic political economies that are shaping their IFRS policies. Then, I inductively isolate two principal dimensions that can be used to characterize these jurisdictions' IFRS responses: proximity to existing political powers at the IASB; and own potential political power at the IASB. Based on how countries are classified along these dimensions, I offer predictions, ceteris paribus, on their IFRS harmonization strategies.

The analysis in this paper helps in the understanding of accounting globalization. Moreover, a knowledge of the international political dynamics of countries' IFRS responses can be useful to the international standard-setting community as IFRS enters its second decade. Fundamental questions in IASB policy that are likely to be informed by international politics remain unanswered. For example, should the IASB put more emphasis on convergence over full adoption in promoting IFRS use? Should the IASB make accommodations to its organizational structure to facilitate U.S. adoption? Should the IASB make further adjustments to its governance to accommodate its growing membership and stakeholder base? The analysis in the paper has implications for these questions, but more research in the political process of the IASB is needed. 


\section{References}

Accounting Standards Board of Japan (ASBJ). 2011. IASB and ASBJ announce their achievements under the Tokyo Agreement and their plans for closer cooperation. Tokyo, ASBJ: June 10.

http://www.asb.or.jp/asb/asb_e/asbj/pressrelease/pressrelease_20110610_e.pd f.

Ahrens, T. and C. Chapman. 2006. Doing qualitative field research in management accounting: Positioning data to contribute to theory. Accounting, Organizations and Society 31: 819-841.

Allen, A. and K. Ramanna. 2012. Towards an understanding of the role of standard setters in standard setting. Journal of Accounting \& Economics forthcoming.

Armstrong, C., M. Barth, A. Jagolinzer, and E. Riedl. 2010. Market reaction to the adoption of IFRS in Europe. The Accounting Review 85: 31-61.

Baker, C., Y. Biondi, and Q. Zhang. 2010. Disharmony in international accounting standards setting: The Chinese approach to accounting for business combinations. Critical Perspectives on Accounting 21: 107-117.

Ball, R. 2006. International Financial Reporting Standards (IFRS): Pros and cons for investors. Accounting and Business Research 36: 5-27.

, S. Kothari, and A. Robin. 2000. The effect of international institutional factors on properties of accounting earnings. Journal of Accounting \& Economics 29: 1-51.

Barth, M. 2006. Research, standard setting, and global financial reporting. Foundations and Trends in Accounting 1, 71-165.

Baskerville, R. 2003. Hofstede never studied culture. Accounting, Organizations and Society 28: 1-14.

Baxter, W. 1981. Accounting standards: boon or curse? Accounting and Business Research 12: 3-10.

Baylin, G., L. MacDonald, and A. Richardson. 1996. Accounting standard setting in Canada, 1864-1992: A theoretical analysis of structural evolution. Journal of International Accounting, Auditing \& Taxation 5: 113-131. 
Benston, G., M. Bromwich, R. Litan, and A. Wagenhofer. 2006. Worldwide financial reporting: The development and future of accounting standards. New York: Oxford University Press.

Biondi, Y. 2011. The pure logic of accounting: A critique of the fair value revolution. Accounting, Economics, and Law 1 (1).

and Q. Zhang. 2007. Accounting for the Chinese context: a comparative analysis of international and Chinese accounting standards focusing on business combinations. Socio-Economic Review 5: 695-724.

Botzem, S. 2012. The politics of accounting regulation: Organizing transnational standard setting in financial reporting. Cheltenham/Northampton, Mass.: Edward Elgar.

- and S. Quack. 2009. (No) Limits to Anglo-American accounting? Reconstructing the history of the International Accounting Standards Committee: A review article. Accounting, Organizations and Society 34: 988998.

Bowles, S. and H. Gintis. 1992. Power and wealth in a competitive capitalist economy. Philosophy \& Public Affairs 21, 324-353.

and -1993 . The revenge of Homo economicus: Contested exchange and the revival of political economy. Journal of Economic Perspectives 7, 83102.

Brackney, K. and P. Witmer. 2005. The European Union's role in international standards setting: Will bumps in the road to convergence affect the SEC's plans? CPA Journal 75 (11), November 1.

Buchanan, A. and R. Keohane. 2006. The Legitimacy of Global Governance Institutions. Ethics and International Affairs 20, 405-437.

Büthe, T. and W. Mattli. 2011. The new global rulers: The privatization of regulation in the world economy. Princeton, N.J.: Princeton University Press.

Camfferman, K., and S. Zeff. 2007. Financial reporting and global capital markets: A history of the international accounting standards committee, 19732000. New York: Oxford University Press.

Canadian Institute of Chartered Accountants (CICA). 2006. Canada's Accounting Standards Board ratifies its strategic plan: Approves convergence with international reporting standards, Toronto. http:/www.cica.ca/news/mediacentre/media-releases-and-backgrounders/2006/item8840.aspx.

Carlile, P. and C. Christensen. 2004. The cycles of theory building in management research. Working Paper \#05-057, Harvard Business School. 
CBC Archives. 1969. Trudeau's Washington Press Club speech. CBC Archives, March 25. http://archives.cbc.ca/politics/prime_ministers/clips/13249/.

CBC News, 2010. WikiLeaks: Do Canadians have an inferiority complex? $C B C$ News, December 1.

Chancellor, E. 2008. Big Bail-Outs Unlikely to Stop the Rot. Financial Times, September 29.

Christoffersen, J. 2008. Board approves new guidance for accounting rules that could help ease financial crisis. Associated Press Newswires, October 10.

DeFond, M., T. Wong, and S. Li. 1999. The impact of improved auditor independence on audit market concentration in China. Journal of Accounting \& Economics 28: 269-305.

Denison, M. 1949. That Inferiority Complex (March 10). Toronto: The Empire Club of Canada. http://speeches.empireclub.org/62586/data.

Department of Commerce (DOC). 2007. Antidumping Methodologies in Proceedings Involving Certain Non-Market Economies: Market-Oriented Enterprise. Federal Register 72 (101), May 25: 29302-29304.

Donnelly, S. 2010. The regimes of European integration: Constructing governance of the single market. New York: Oxford University Press.

Economist, The. 2010. India and China: A Himalayan rivalry. The Economist, August 19.

EC (European Commission). 2000. EU Financial Reporting Strategy: The Way Forward. Brussels, Belgium: EC. http://www.iasplus.com/resource/cec.pdf.

- 2005. Council Regulation No. 1174/2005. Brussels, Belgium: Official Journal of the European Union. http://eurlex.europa.eu/LexUriServ/LexUriServ.do?uri=OJ:L:2005:189:0001:0014:EN: PDF.

. 2008. Immediate responses to financial turmoil, Council ConclusionsEcofin Council of 7 October 2008. Luxembourg: EC. http://www.consilium.europa.eu/uedocs/cms_Data/docs/pressdata/en/misc/10 3202.pdf.

- 2009. Council Regulation No. 1225/2009. Brussels, Belgium: Official Journal of the European Union. http://trade.ec.europa.eu/doclib/docs/2010/april/tradoc_146035.pdf.

_ 2010. Council Regulation No. 1042/2010. Brussels, Belgium: Official Journal of the European Union. http://eur- 
lex.europa.eu/LexUriServ/LexUriServ.do?uri=OJ:L:2010:299:0007:0028:EN: PDF.

European Parliament. 2002. Proposal for a European Parliament and Council regulation on the application of international accounting standards. Brussels, Belgium: European Parliament.

http://www.europarl.europa.eu/sides/getDoc.do?type $=$ REPORT\&reference $=\mathrm{A}$ 5-2002-0070\&language $=\mathrm{EN}$.

Fernández, R. 2008. Culture and economics. In S. Durlauf and L. Blume (Eds.), The New Palgrave Dictionary of Economics Online. Palgrave Macmillan.

Gray, T. and A. Kitching. 2005. Reforming Canadian Securities Regulation. Ottawa, Canada: Parliament Information and Research Service. http://www.parl.gc.ca/Content/LOP/ResearchPublications/prb0528-e.htm

Hawkins D., K. Ramanna, N. Sato, and M. Yamazaki. 2011. Deferred Tax Assets in Basel III: Lessons from Japan. Harvard Business School Case 111-076.

Heidhues, E. and C. Patel. 2011. IFRS and exercise of accountants' professional judgments: Insights and concerns from a German perspective. Working Paper, Macquarie University.

Hofstede, G. 2001. Culture's consequences, second edition: comparing values, behaviors, institutions and organizations across nations. Thousand Oaks, Calif.: Sage.

Hope, T. and R. Gray. 1982. Power and policy making: The development of an R\&D standard. Journal of Business Finance \& Accounting 9, 531-558.

Hopper, T. 2011. 'Royal' returns for Canada's armed forces. National Post, August 15.

Humphrey, C., A. Loft, and M. Woods. 2009. The global audit profession and the international financial architecture: Understanding regulatory relationships at a time of financial crisis. Accounting, Organizations and Society 34: 810-825.

Hurrell, A. 2005. Legitimacy and the Use of Force: Can the Circle Be Squared? Review of International Studies 31, 15-32.

International Accounting Standards Board (IASB). 2007. India announces convergence with IFRSs for public interest entities from 2011. London: IASB, July 24 . http://www.ifrs.org/News/Press+Releases/India+announces+convergence+wit $\mathrm{h}+\mathrm{IFRSs}+$ for+public+interest+entities+from+2011.htm.

— 2009. IASB simplifies requirements for disclosure of related party transactions. London: IASB, November 4. 
http://www.ifrs.org/News/Press+Releases/IASB+simplifies+requirements+for + disclosure + of + related + party + transactions.htm.

IFRS Foundation. 2009. Trustees enhance public accountability through new monitoring board, complete first part of Constitution Review. London: IFRS Foundation, January 29. http://www.ifrs.org/NR/rdonlyres/6A31C6E6-423D4C6D-A18CD82DFEBE8FD9/0/PRTrusteesenhancepublicaccountability.pdf.

International Trade Administration (ITA). 2007. Public Comments Received on Antidumping Methodologies in Proceedings Involving Certain Non-Market Economies: Market-Oriented Enterprise (72 FR 29302). Washington, D.C.: ITA, June 25. http://ia.ita.doc.gov/download/nme-moe/nme-moe-cmt20070625-index.html.

Jefferson, T. 2006. The Papers of Thomas Jefferson, Vol. 33: 17 February to 30 April 1801 (B. Oberg, Ed.) Princeton, N.J.: Princeton University Press. http://www.princeton.edu/ tjpapers/.

Johnson, S. 2010. IFRS North of the Border. CFO.com, August 25.

Jones, A. 2009. Impetus Fades on Project to Amalgamate Standards. Financial Times, October 7.

Kennedy, J. 1961. Address of President-Elect John F. Kennedy Delivered to a Joint Convention of the General Court of the Commonwealth of Massachusetts (January 9). Boston, Mass: John F. Kennedy Presidential Library and Museum. http://www.jfklibrary.org/Research/.

Khanna, T. 2007. Billions of entrepreneurs: How China and India are reshaping their futures and yours. Boston, Mass.: Harvard Business School Press.

Kissinger, H. 2011. On China. New York: The Penguin Press.

Kothari, S., K. Ramanna, and D. Skinner. 2010. Implications for GAAP from an analysis of positive research in accounting. Journal of Accounting \& Economics 50: 246-286.

Kranacher, M. 2010a. An Interview with Ian Mackintosh. CPA Journal 80 (6), July 1.

- 2010b. Bringing the World Together on One Standard. CPA Journal 80 (10), October 1.

La Porta, R., F. Lopez-de-Silanes, and A. Shleifer. 2008. The economic consequences of legal origins. Journal of Economic Literature 46: 285-332.

Langmead, J. and J. Soroosh. 2009. International Financial Reporting Standards: The Road Ahead. CPA Journal 79 (3), March 1. 
Laux, C. and C. Leuz. 2009. The crisis of fair-value accounting: Making sense of the recent debate. Accounting, Organizations and Society 34: 826-834.

Leone, M. 2008. “Spineless?” UK pressure targets fair value weakening. CFO.com, November. http://www.cfo.com/article.cfm/12586836?f=related.

Leuz, C. 2010. Different approaches to corporate reporting regulation: How jurisdictions differ and why. Accounting and Business Research 40: 229-256.

_ D. Pfaff, and A. Hopwood. 2005. The Economics and Politics of Accounting: International Perspectives on Research Trends, Policy, and Practice. Oxford: Oxford University Press.

Ministry of Corporate Affairs (MCA). 2011. Press Release No. 1/1/2009-IFRS. New Delhi: MCA. http://www.mca.gov.in/.

Ministry of Finance (MOF). 2008. Analysis of the situation related to the implementation of new accounting standards by China's listed companies in 2007 [in Chinese]. Beijing: Accounting Regulatory Department, MOF. http://kjs.mof.gov.cn/kjs/zhengwuxinxi/diaochayanjiu/200807/t20080703_558 29.html.

Moneycontrol. 2007. Tata Corus Taking Big Steps to Streamline Ops. Moneycontrol, October 13.

Norris, F. 2010. New Cast Enters Fight in Accounting. New York Times, October 22.

Nye, J. 1974. Multinational corporations in world politics. Foreign Affairs 53: $153-175$.

Parker, A. 2003. European banks slam derivative proposals. Financial Times, March 11.

Perry, J. and A. Nölke. 2005. International accounting standard setting: A network approach. Business and Politics 7 (3).

Perry, J. and A. Nölke. 2006. The political economy of international accounting standards. Review of International Political Economy 13: 559-586.

Power, M. 1992. The politics of brand accounting in the United Kingdom. European Accounting Review 1: 39-68.

Press Information Bureau (PIB). 2008. PM addresses the Tata Centenary celebrations. New Delhi: PIB, Government of India, April 22. http://www.pib.nic.in/release/release.asp?relid=37731.

Puro, M. 1984. Audit firm lobbying before the Financial Accounting Standards Board: An empirical study. Journal of Accounting Research 22: 624-646. 
Ramanna, K. 2008. The implications of unverifiable fair-value accounting: Evidence from the political economy of goodwill accounting. Journal of Accounting \& Economics 45: 253-281.

and B. Cheng. 2009. Choosing a GAAP for Canada. Harvard Business School Case 110-023.

, G. Donovan, and N. Dai. 2009. IFRS in China. Harvard Business School Case 110-037.

, K. Misztal, and D. Beyersdorfer. 2011. The IASB at a Crossroads: The Future of International Financial Reporting Standards. Harvard Business School Case 111-084.

and E. Sletten. 2009. Why do countries adopt International Financial Reporting Standards? Working Paper \#09-102, Harvard Business School.

and -2011 . Network effects in countries' adoption of IFRS. Working Paper \#10-092, Harvard Business School.

_ and R. Tahilyani. 2010. Leadership in Corporate Reporting Policy at Tata Steel. Harvard Business School Case 111-028.

Reagan, R. 1989. Farewell Address to the Nation (January 11). Simi Valley, Calif.: Ronald Reagan Presidential Library and Museum. http://www.reagan.utexas.edu/archives/speeches/.

Richardson, A. 2009. Regulatory networks for accounting and auditing standards: A social network analysis of Canadian and international standard-setting. Accounting, Organizations and Society 34: 571-588.

Sanderson, R. 2009. Europe's Schism Threatens Global Accounting Rules. Financial Times, November 16.

Securities and Exchange Commission (SEC). 2007. SEC Takes Action to Improve Consistency of Disclosure to U.S. Investors in Foreign Companies.

Washington D.C.: SEC, November 15. http://www.sec.gov/news/press/2007/2007-235.htm.

- 2008. Roadmap for the Potential Use of Financial Statements Prepared in Accordance with International Financial Reporting Standards by U.S. Issuers. Washington D.C.: SEC, November 14. http://www.sec.gov/rules/proposed/2008/33-8982.pdf.

. 2012. Work Plan for the Consideration of Incorporating International Financial Reporting Standards into the Financial Reporting System for U.S. Issuers. Washington D.C.: SEC, July 13. 
http://sec.gov/spotlight/globalaccountingstandards/ifrs-work-plan-finalreport.pdf.

Simmons, E. 2001. The international politics of harmonization: The case of capital market regulation. International Organization 55: 589-620.

Skinner, D. 2008. The rise of deferred tax assets in Japan: The role of deferred tax accounting in the Japanese banking crisis. Journal of Accounting \& Economics 46: 218-239.

Sunder, S. 2011. Imagined worlds of accounting. Accounting, Economics, and Law 1 (1).

Sweeney, J. 2009. Are Global Standards Bad for America? Business Finance, July 1.

Tang, Y. 2000. Bumpy Road Leading to Internationalization: A Review of Accounting Development in China. Accounting Horizons 14: 93-102.

Tata Steel. 2008. Annual Report for 2007-2008. Mumbai: Tata Steel.

Tiwari, D. and S. Sanyal. 2010. House panel seeks to push date for IFRS switch by two years. The Economic Times, December 7.

de Tocqueville, A. 2004. Democracy in America. New York: Library of America.

United Nations Organization (UNO). 1958. United Nations Treaty Series, Vol. 299. New York: UNO.

Watts, R. and J. Zimmerman. 1978. Towards a positive theory of the determination of accounting standards. The Accounting Review 53: 112-134. and 1982 . Auditors and the determination of accounting standards. Working Paper \#GPB 78-06, University of Rochester.

World Bank. 2009. Report on the observance of standards and codesAccounting and auditing: People's Republic of China. Washington, DC: The World Bank Group. http://www.worldbank.org/ifa/rosc_china.html.

World Trade Organization (WTO). 2001. Accession of the People's Republic of China. Geneva: WTO. http://www.wto.org/english/thewto_e/acc_e/protocols_acc_membership_e.ht $\mathrm{m}$.

Young, J. 1994. Outlining regulatory space: Agenda issues and the FASB. Accounting, Organizations and Society 19: 83-109.

- 2003. Constructing, persuading and silencing: The rhetoric of accounting standards. Accounting, Organizations and Society 28: 621-638. 
Zeff, S. 1972. Forging accounting principles in five countries: A history and an analysis of trends. Champaign, IL: Stipes Publishing Company. 